\title{
Structure and tectonics of the northern Red Sea: catching a continental margin between rifting and drifting
}

\author{
FERNANDO MARTINEZ * and JAMES R. COCHRAN \\ Lamont-Doherty Geological Observatory of Columbia University, Palisades, NY 10964 (U.S.A.)
}

(Received by publisher January 12, 1988)

\begin{abstract}
Martinez, F. and Cochran, J.R., 1988. Structure and tectonics of the northern Red Sea: catching a continental margin between rifting and drifting. In: E. Bonatti (Editor), Zabargad Island and the Red Sea Rift. Tectonophysics, 150: 1-32.

The northern Red Sea is a continental rift that has developed nearly to the point where seafloor spreading initiates. We present new geophysical data from the northern Red Sea which bear on how the transition from continental rifting to seafloor spreading takes place.

Two distinct provinces within the "main trough" of the northern Red Sea in the area north of $26^{\circ} \mathrm{N}$ latitude have been identified which are referred to here as the "marginal areas" and the "axial depression". The marginal areas form a series of bathymetric terraces that step down from the eastern and western shelves toward the central part of the Red Sea. Geophysical data indicate that the marginal areas are underlain by faulted and tilted basement blocks with structural characteristics similar to those observed at "sediment starved" passive margins. Seismic reflection profiles show that recent deformation in the overlaying sediments of the marginal areas has been relatively widely spaced, episodic in places and, although the deformation continues to the present, it is generally decreasing with time.

The axial depression forms a continuous narrow zone of deeper water which is located near the center of the Red Sea except in the northernmost part where it shifts to the west in alignment with the entrance to the Gulf of Suez. Sediments in the axial depression exhibit a more intense and closely spaced deformation which appears to continue in activity to the present. Seismic activity in the northern Red Sea south of the Gulf of Suez area is concentrated in the axial depression and heat flow profiles across the main trough show maximum values which occur consistently over the axial depression. These observations indicate that the extension and tectonic activity which had previously been * distributed across the rift, are becoming localized in the axial depression.

Three major cross-trending "accommodation zones" partition the rift into fault block provinces along strike and serve to take up differential motion between blocks. Small "deeps" occur at various locations in the northern Red Sea. In particular, a series of these is associated with large isolated dipolar magnetic anomalies which appear to result from large intrusions. These intrusion-associated deeps occur at evenly spaced intervals in the axial depression, midway between sets of accommodation zones. This suggests that the accommodation zones may structurally control the emplacement of these intrusions and the formation of the associated deeps. These deeps appear to represent precursors to localized seafloor spreading, such as occurs in the large "transition zone" deeps farther south in the central Red Sea. Geophysical and morphologic evidence suggests that the large transition zone deeps of the central Red Sea represent isolated propagating seafloor spreading cells which eventually may coalesce to form a continuous seafloor spreading axis. The seafloor spreading axis of the southern Red Sea may have formed by this process.
\end{abstract}

\section{Introduction}

* Also Department of Geological Sciences, Columbia University.
The Red Sea forms part of a rift system that includes the Gulf of Aden and East African rift in 
the south and the Gulf of Suez and Gulf of Aqaba in the north. These rifts initiated in the late Oligocene-Miocene time and fragment the once continuous Afro-Arabian shield.

The Red Sea extends for $1920 \mathrm{~km}$ from Ras Muhammad at the southern tip of the Sinai Peninsula to the Straits of Bab al Mandeb at the entrance to the Gulf of Aden. From Ras Gemsa at the mouth of the Gulf of Suez to Ras Benas at $24^{\circ} \mathrm{N}$, a distance of $458 \mathrm{~km}$, the African and Arabian coastlines are remarkably straight and parallel with a separation of about $190 \mathrm{~km}$. South of here the coastlines become sinuous and the sea gradually widens to its maximum width of about $350 \mathrm{~km}$ between $16^{\circ} \mathrm{N}$ and $17^{\circ} \mathrm{N}$ and then narrows to about $40 \mathrm{~km}$ at the southern straits.

Irregular eroded escarpments face seaward from the uplifted basement rift shoulders that surround the Red Sea. The rift shoulders average between 1000 and $3000 \mathrm{~m}$ in elevation and expose PanAfrican age granitic, metamorphic and volcanic rocks which may have formed as a result of granitic plutonism (Stern et al., 1984) and accretion of exotic terrains including ophiolites (Stoeser and Camp, 1985).

The Red Sea occupies an elongate "main trough" that has depths ranging from several hundred meters to about $1200 \mathrm{~m}$ and in the south (from $15^{\circ} \mathrm{N}$ to $20^{\circ} \mathrm{N}$ ), is bisected by a narrow (less than about $60 \mathrm{~km}$ ) "axial trough" having depths up to about $2000 \mathrm{~m}$. The main trough is generally surrounded by narrow marginal shelves and coastal plains. However, south of about $20^{\circ} \mathrm{N}$ on the eastern side and $17^{\circ} \mathrm{N}$ on the western side, reefs and carbonate banks begin to widen and almost completely fill in the main trough.

The Red Sea can be divided into three distinct areas with different morphologies and geophysical characteristics that have been interpreted (Cochran, 1983) as representing different stages in the evolution of the rift (Fig. 1). These areas consist of a southern section (from $15^{\circ}$ to about $20^{\circ} \mathrm{N}$ ) in which active seafloor spreading is occurring, a central transition zone (from $20^{\circ}$ to about $23.5^{\circ} \mathrm{N}$ ) which contains isolated cells of seafloor spreading, and a northern section (from $23.5^{\circ}$ to $28^{\circ} \mathrm{N}$ ) which is currently in the late stages of continental rifting.
Seafloor spreading magnetic anomalies have been identified in the southern section in the narrow, steep-sided axial trough. The axial trough appears to have been created by organized seafloor spreading that commenced 4-5 m.y.B.P. near $17^{\circ} \mathrm{N}$ and propagated north and south from there to $20^{\circ} \mathrm{N}$ and $15^{\circ} \mathrm{N}$ where anomalies can only be correlated to 2 or 3 m.y.B.P. (Roeser, 1975). The main trough outside the axial trough has only low amplitude magnetic anomalies that appear to reflect a faulted and tilted basement structure (Cochran, 1983).

North of $20^{\circ} \mathrm{N}$ to about $23^{\circ} 30^{\prime} \mathrm{N}$ the axial trough becomes discontinuous forming a series of large deeps spaced at intervals of about $50 \mathrm{~km}$. These deeps have lineated magnetic anomalies which indicate that organized seafloor spreading has been taking place for less than 2 m.y. (Bonatti et al., 1984). The deeps are separated by intertrough zones that have continuous sedimentary sequences across them and low amplitude magnetic anomalies (Searle and Ross, 1975) indicating that seafloor spreading has not yet occurred there.

The third zone, north of $23^{\circ} 30^{\prime} \mathrm{N}$, has been interpreted (Cochran, 1983) as representing late stage continental extension. The morphology of the northern Red Sea has the general form of a broad basin with shallow marginal areas stepping down toward a distinct zone of deeper water at about $1200 \mathrm{~m}$ referred to as the "axial depression" (Cochran et al., 1986).

With the possible exception of Mabahiss Deep located at $25^{\circ} 25^{\prime} \mathrm{N}$ (Pautot et al., 1986), no center of organized seafloor spreading has been identified in this area and block faulting and salt deformation are the main forms of tectonic activity in this northern zone. Mabahiss Deep is a large deep with maximum depths of about $2000 \mathrm{~m}$ over which Pautot et al. (1986) have reported lineated magnetic anomalies. However, the deep has a flat bottom and lacks the characteristic morphology of an organized seafloor spreading center.

Small isolated depressions generally referred to as deeps occur at various places in the northern Red Sea. Some of these deeps contain hot or cold brines and metalliferous sediments (Bäcker and Schoell, 1972) or occur coincident with or in close proximity to high amplitude dipolar magnetic 


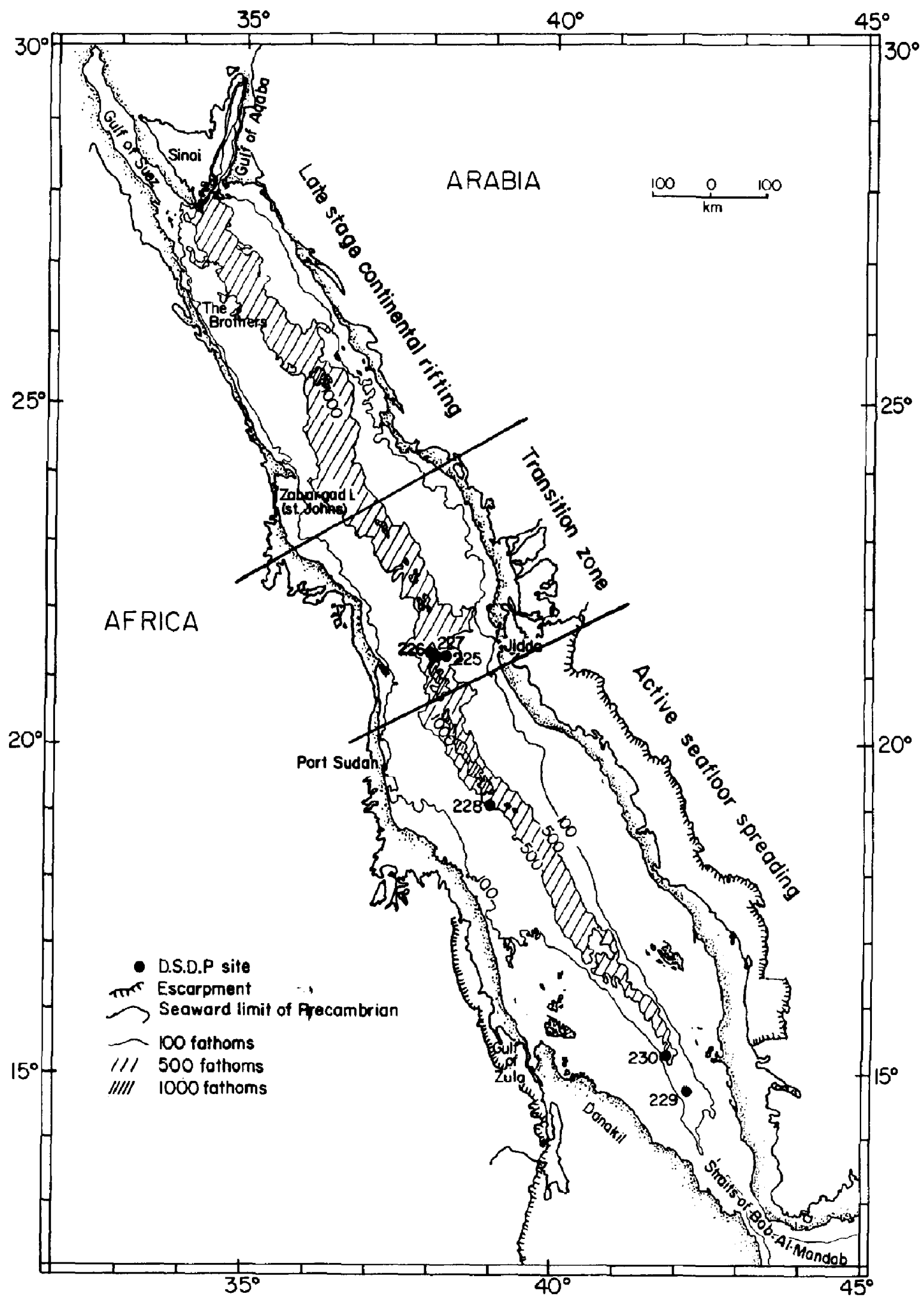

Fig. 1. Map of Red Sea showing division into three sections representing different stages in the development of the margin. Southern section is bisected by a narrow "axial trough" formed by active seafloor spreading. Northward in the "transition zone" the axial trough is replaced by periodically spaced large deeps forming isolated cells of seafloor spreading separated by "intertrough zones". The northern section of the Red Sea is in the last stages of continental extension. 
anomalies. These magnetic anomalies have been interpreted to result from the emplacement of isolated intrusions into stretched and thinned continental crust (Pautot et al., 1986; Cochran, 1983; Cochran et al., 1986).

The purpose of this study is to describe the structure and presently active tectonics of the northern Red Sea and to relate them to the evolution of the transition from continental rifting to seafloor spreading.

\section{Data acquisition}

R/V "R.D. Conrad" made a detailed survey of the Red Sea north of $26^{\circ} \mathrm{N}$ in the summer of 1984. Data collected on that cruise forms the primary basis of this study (see Fig. 2 for location).

A Loran-C chain in Saudi Arabia made it possible to obtain navigation fixes at one minute intervals for $73 \%$ of the survey, the remainder being navigated by dead reckoning tied to standard transit satellite fixes. The raw Loran positions were smoothed using a running average filter to remove the short period "jitter" and produce a smooth Eotvos correction for the gravity. Loran positions were compared with 303 transit satellite positions that were taken simultaneously and an average discrepancy of $317 \mathrm{~m}$ was determined. Based on a study (Talwani, 1970) that showed that repeat transit satellite fixes tend to cluster about the true geographic position, the Loran positions were shifted as a unit to remove the average discrepancy with the satellite fixes. Based on the standard deviation of satellite-Loran discrepancies the resulting navigation is estimated to have an absolute accuracy of better than $400 \mathrm{~m}$. From the agreement of Sea Beam bathymetry contours at intersecting track lines taken several days apart, an internal precision of about $50 \mathrm{~m}$ is estimated.

The data collected included single channel water gun and air gun seismic reflection profiles, 3.5 and $12 \mathrm{kHz}$ precision depth recordings, Sea Beam multibeam echo soundings, total intensity magnetics, gravity using a BGM-3 gravitimeter, nearly 200 temperature gradient measurements in three heat flow traverses across the Red Sea and ten piston core samples for thermal conductivity determination.
The underway gravity survey was conducted using a Bell Aerospace BGM-3 marine gravity meter system that was installed on the $R / V$ " Robert $\mathrm{D}$. Conrad" in 1984. The system consists of a vertical component forced feedback accelerometer that is not subject to cross coupling errors mounted on a gyro-stabilized platform. The performance of this system is described in detail by Bell and Watts (1986). In the Red Sea, gravity data values were obtained at $1 \mathrm{~min}$ intervals with discrepancies at ship track intersections of less than about 1 $\mathrm{mGal}$ for the Loran-C navigated sections and not more than about $3 \mathrm{mGal}$ in the worst cases. Data from previous cruises in the area were included in our contour map if discrepancies at intersections of individual ship tracks and the scatter of their discrepancies at intersections with our data was less than about $7 \mathrm{mGal}$. Those cruises satisfying the above criteria had their data adjusted by adding a constant to remove the average gravity discrepancy at intersections with our cruise.

Oil industry seismic reflection studies using 48 channel streamers with airgun sources and well data show the presence of a thick ubiquitous evaporite sequence underlying the main trough in the northern Red Sea (Barakat and Miller, 1984). Although the industry surveys had some success in imaging the bottom of the cvaporite layer in places, in no case have they been able to resolve the underlying basement structure (P. Miller, pers. commun., 1986). Our seismic survey of the area therefore emphasized the use of high frequency watergun seismic sources in an effort to resolve details of the deformation in the evaporites and overlaying sediments which record the latest tectonic activity. The use of waterguns and a single channel streamer also greatly simplified processing of the data since the sharp output pulse did not require deconvolution.

Underway Sea Beam data were acquired for most of the cruise. This system, which uses sixteen narrow $12 \mathrm{kHz}$ beams, produces swath contour strips in near real time which cover a width of about $80 \%$ of the water depth and have a relative accuracy of $10-15 \mathrm{~m}$. This system proved to be extremely valuable even in relatively shallow water for defining trends and mapping small-scale features which otherwise could not have been identi- 


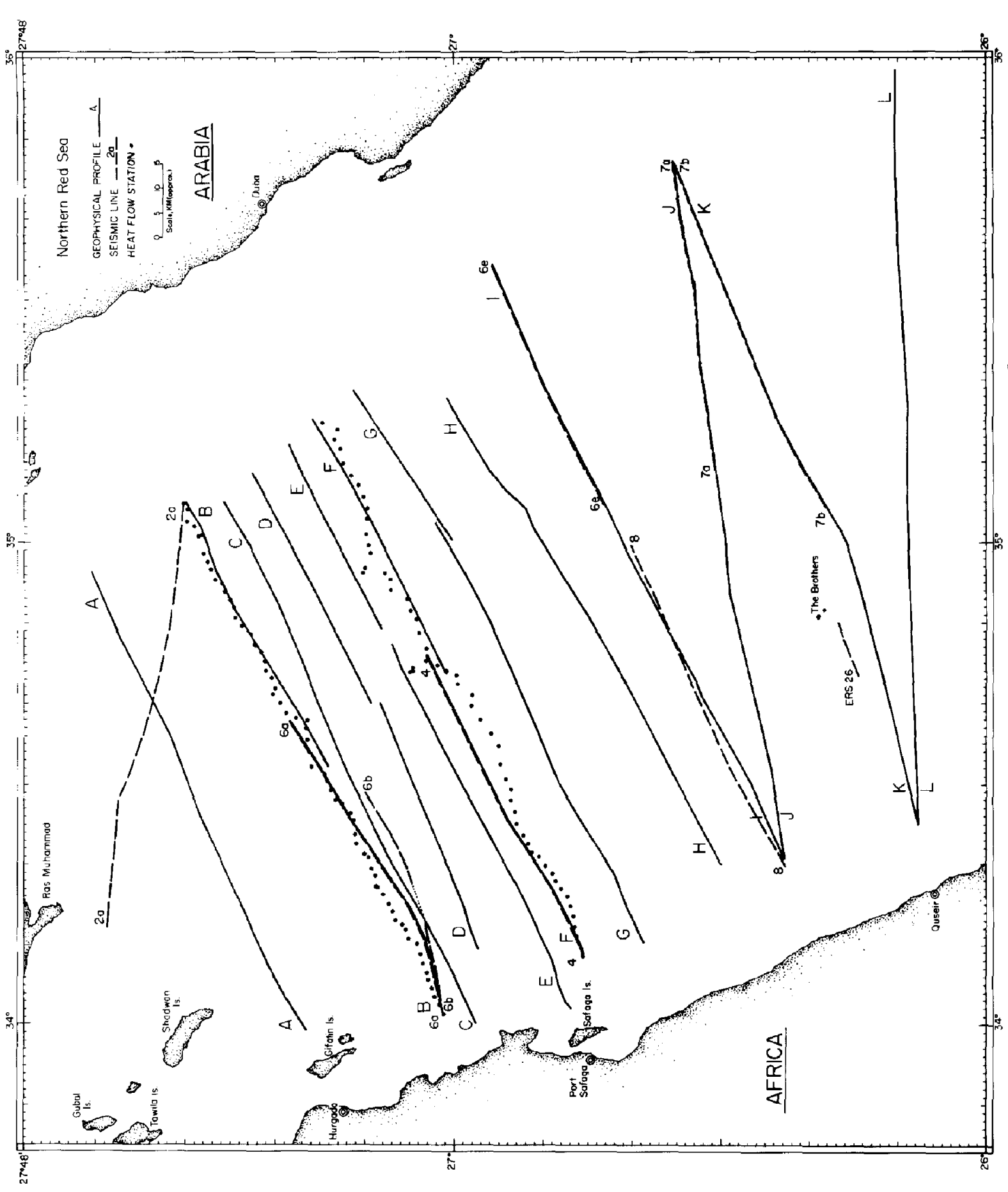


fied on conventional bathymetric profiles.

Heat flow data were acquired using the L-DGO "pogo probe" apparatus. This device consists of seven thermistors mounted on a $5 \mathrm{~m}$ lance with an additional thermistor on top to determine bottom water temperature. Temperature profiles were acquired on three profiles across the Red Sca comprising 191 stations spaced 1 to $2 \mathrm{~km}$ apart. The three profiles were spaced about $70 \mathrm{~km}$ apart. Thermal conductivities were determined from sediments recovered in ten piston cores. The cores were spaced so as to sample systematic variations in conductivities from the shallow marginal areas to the deeper central area.
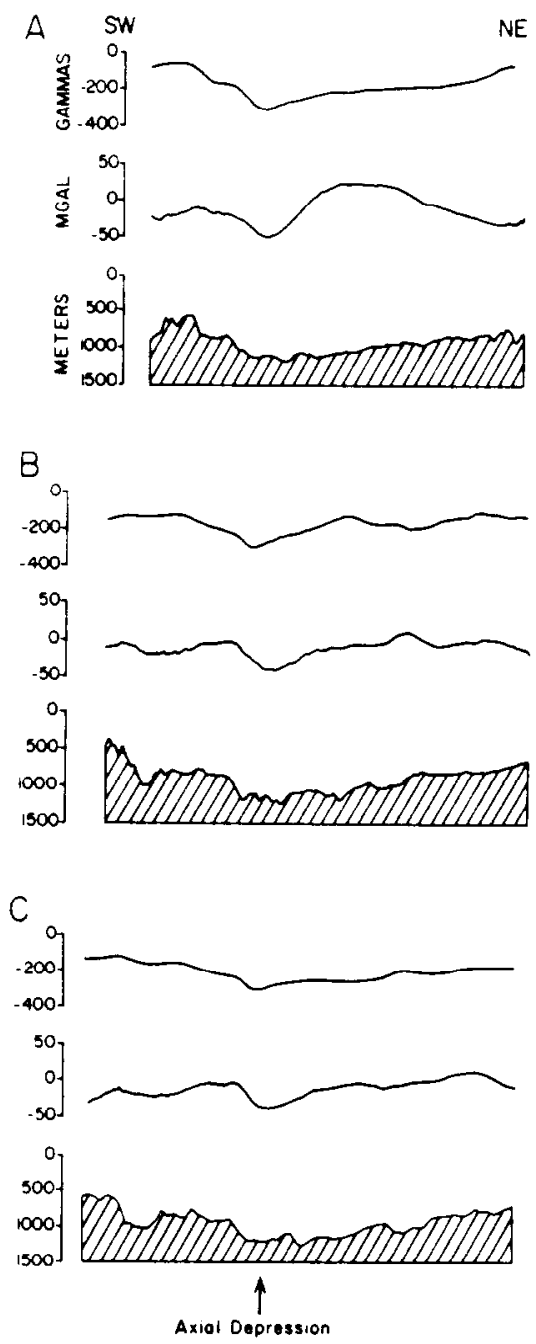

\section{Geologic setting}

Geophysical profiles across the northern Red Sea are shown in Fig. 3 and a location map is shown in Fig. 2. The bathymetry has a blocky somewhat asymmetric appearance. On the western side, narrow 5-10 km wide marginal shelves abruptly drop down to the main trough at depths greater than $400 \mathrm{~m}$. The western side of the main trough consists of a set of 20 to $30 \mathrm{~km}$ wide terraces which can be seen in the bathymetric map (Fig. 4) to generally occur at depths of about 500, 800 , and $1000 \mathrm{~m}$. These terraces have an irregular surface with local relief which may vary by $100 \mathrm{~m}$
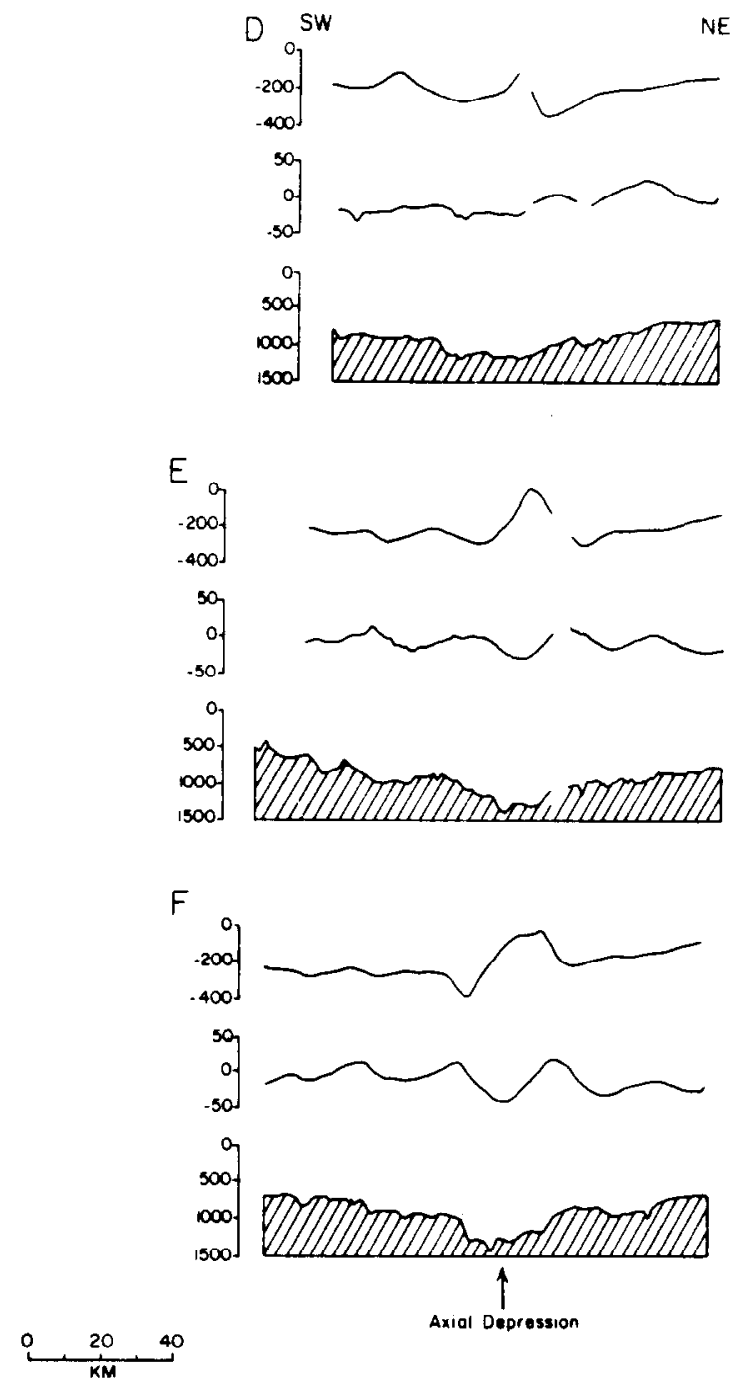

$\mathrm{F}$

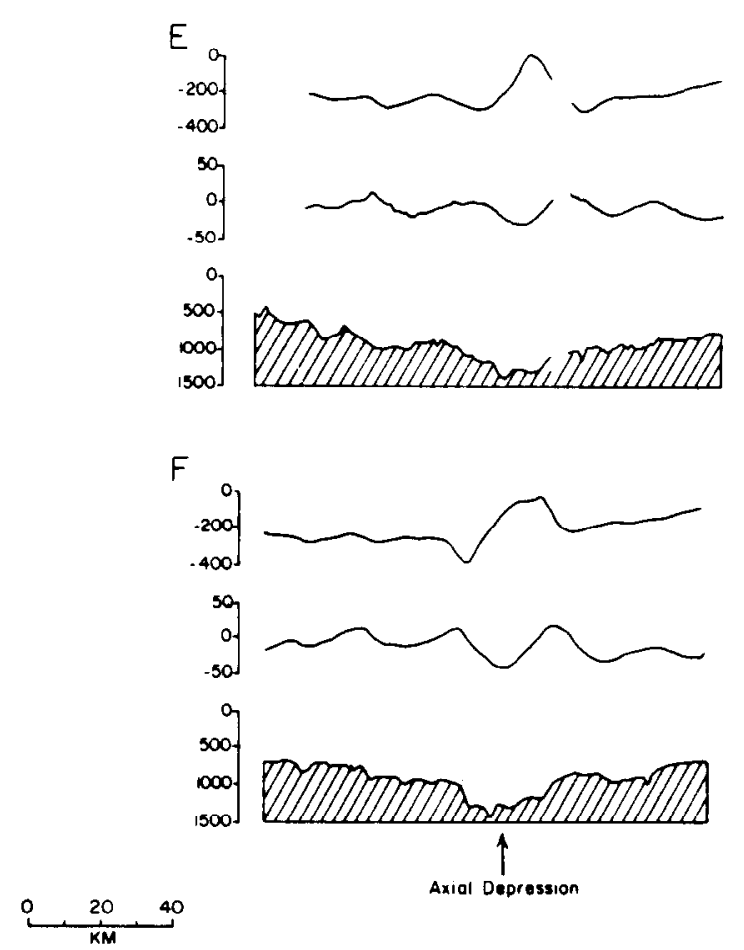

Fig. 3. Geophysical profiles across the northern Red Sea projected at $\mathrm{N} 60^{\circ} \mathrm{E}$ and stacked on the axial depression. Bathymetry is in corrected meters, free-air gravity anomalies in milligals, and total intensity magnetic anomalies in gammas. Location of profiles is shown in Fig. 2. 

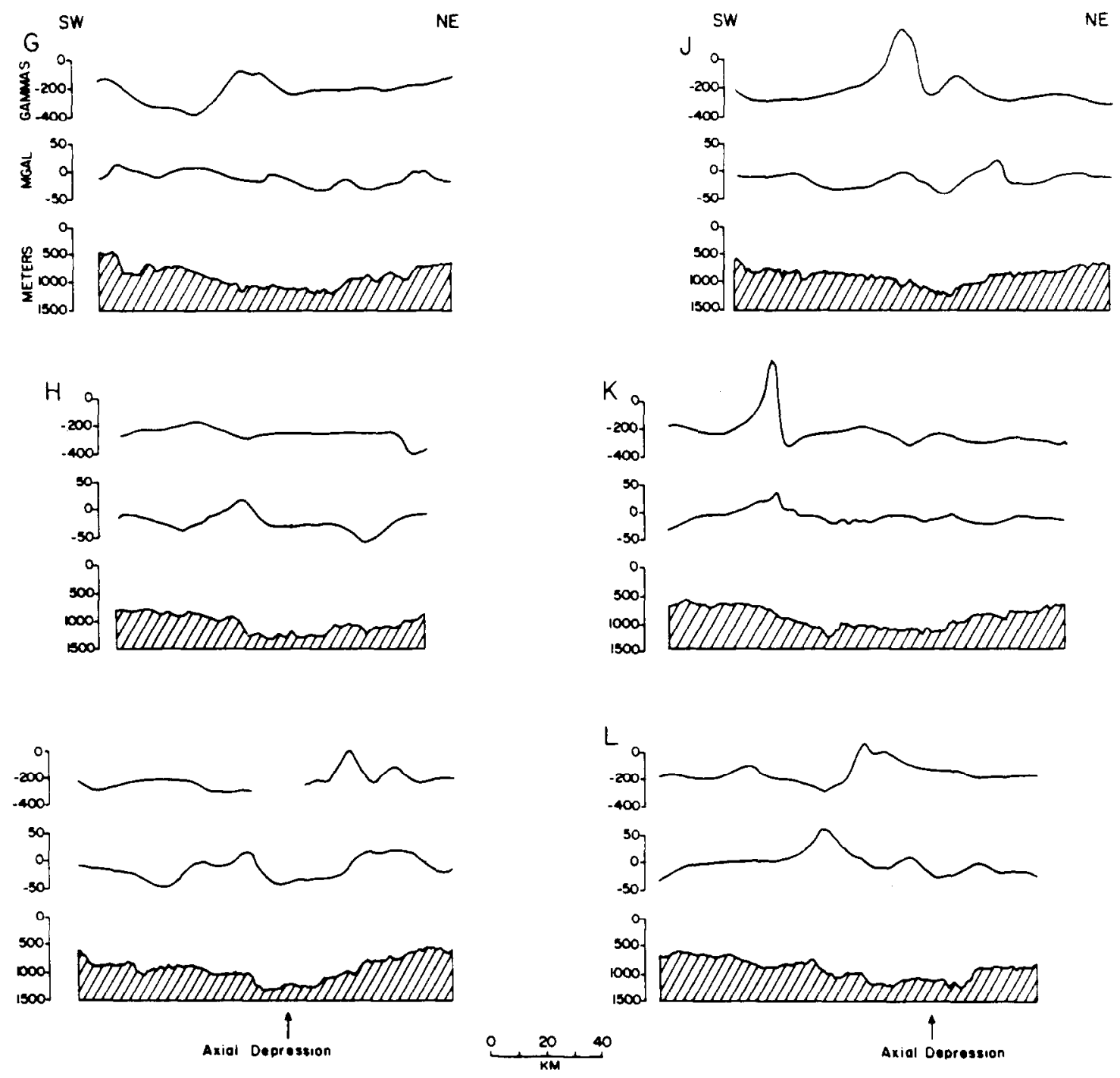

Fig. 3 (continued).

or more over distances of 1 or $2 \mathrm{~km}$. The terraces are often separated by steep escarpments which appear in many cases to be faults.

On the eastern side, terraces are not as well defined. Although there are places where distinct levels are separated by fault bounded escarpments, slope gradients tend to be less steep than on the west giving the main trough a less blocky appearance and more the form of an irregular slope, particularly in the northeastern section. The marginal shelves are also wider on the eastern side with reefs extending $20 \mathrm{~km}$ or more from the shore.
A consistent feature of the main trough in the northern Red Sea is an axis of deeper water $1100-1200 \mathrm{~m}$ deep and from 10 to about $25 \mathrm{~km}$ wide referred to here as the axial depression. The axial depression differs from the axial trough of the southern Red Sea in that sedimentary sequences, including upper Miocene reflector $S$, are continuous across it, high amplitude lineated magnetic anomalies are not associated with it, and it is much shallower. The axial depression is often fault bounded and is located near the center of the main trough except at the northernmost part of the Red Sea where it shifts to the west and be- 


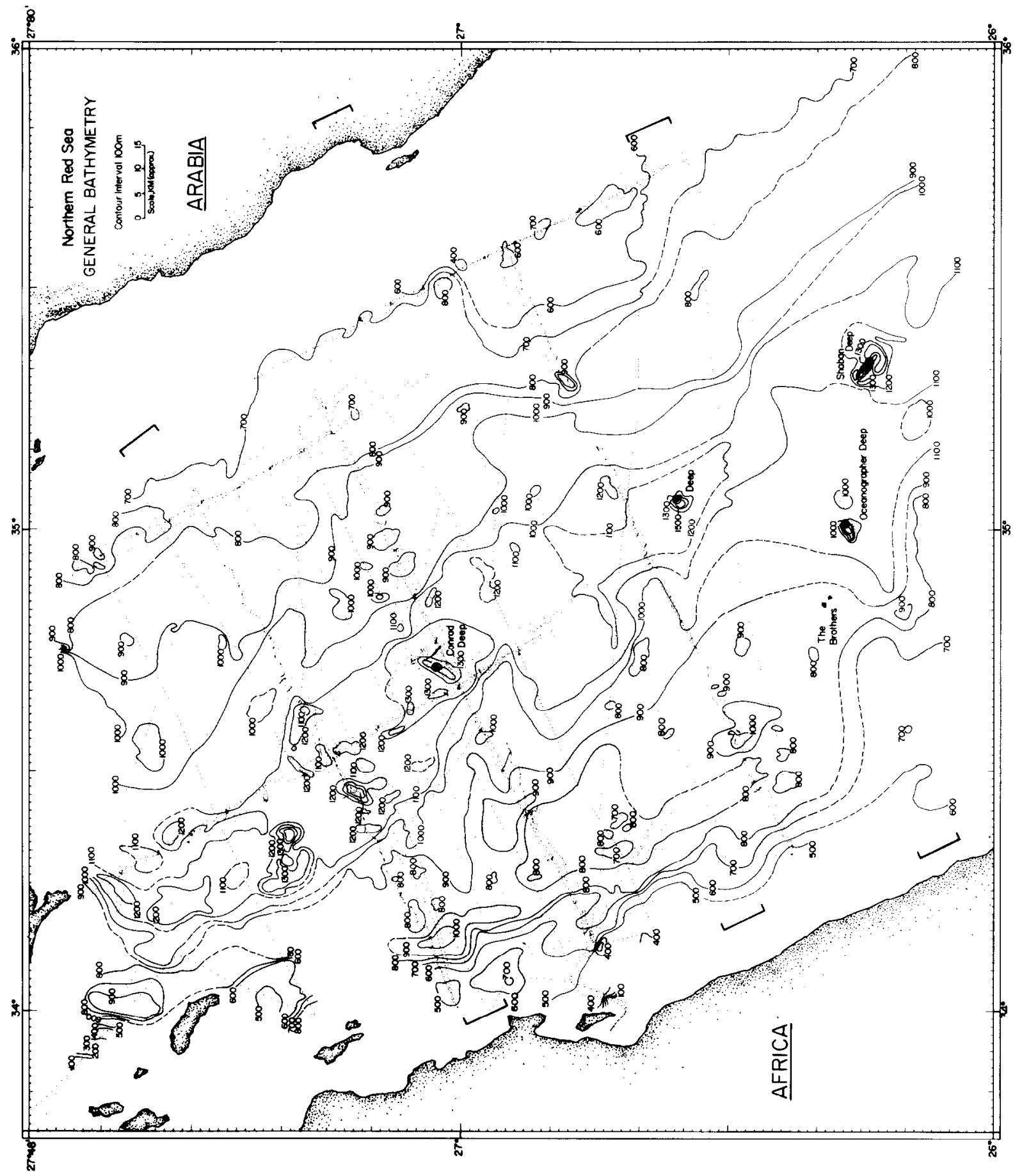

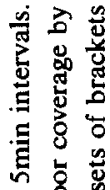

ㄷ․ㅁ

कू⿻

:

8 요

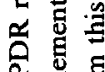

형 을

은

马 퐁

莺言

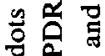

密表

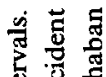

. ․․ㅇํㅇ

동 훙

范密

马 


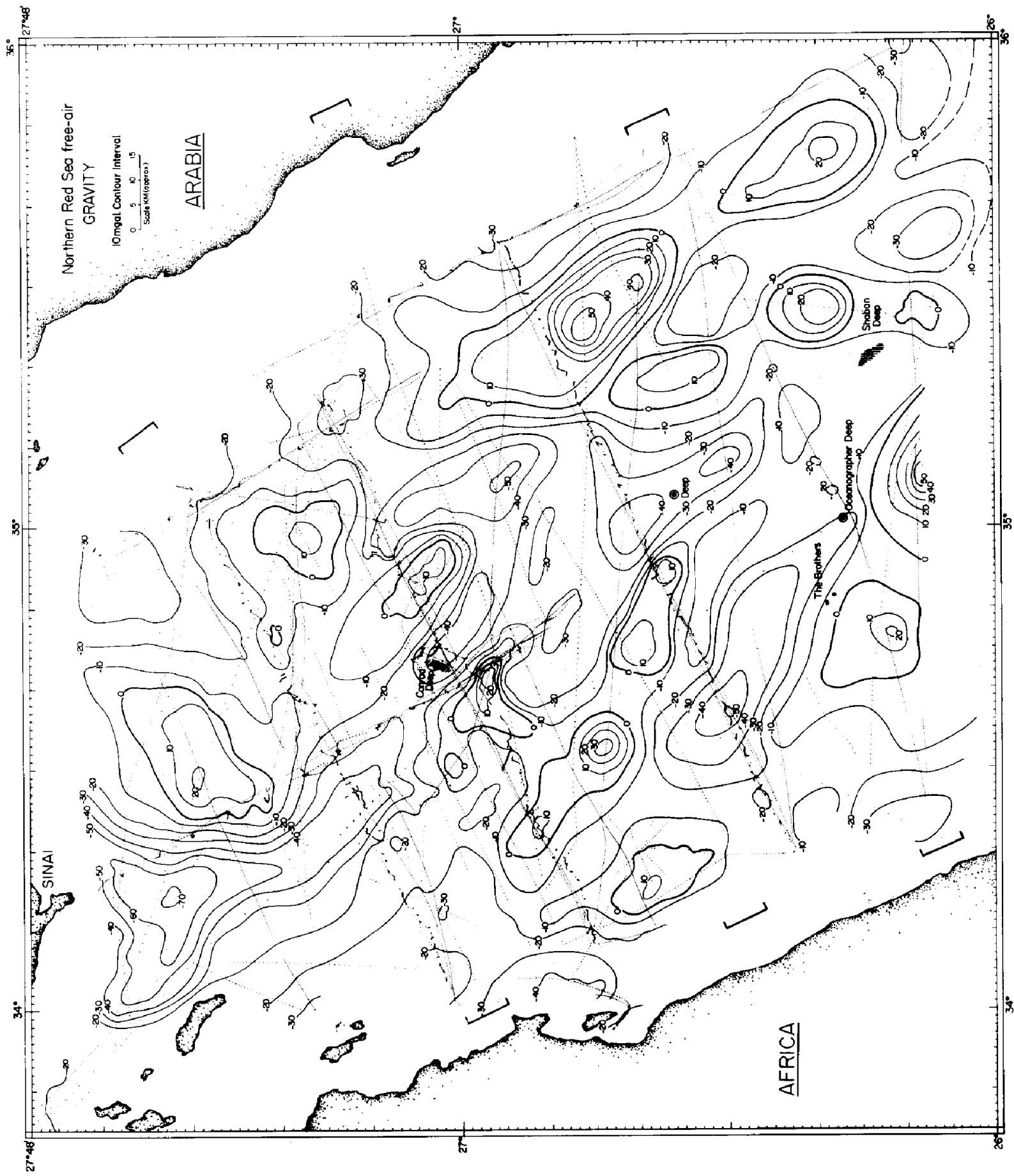



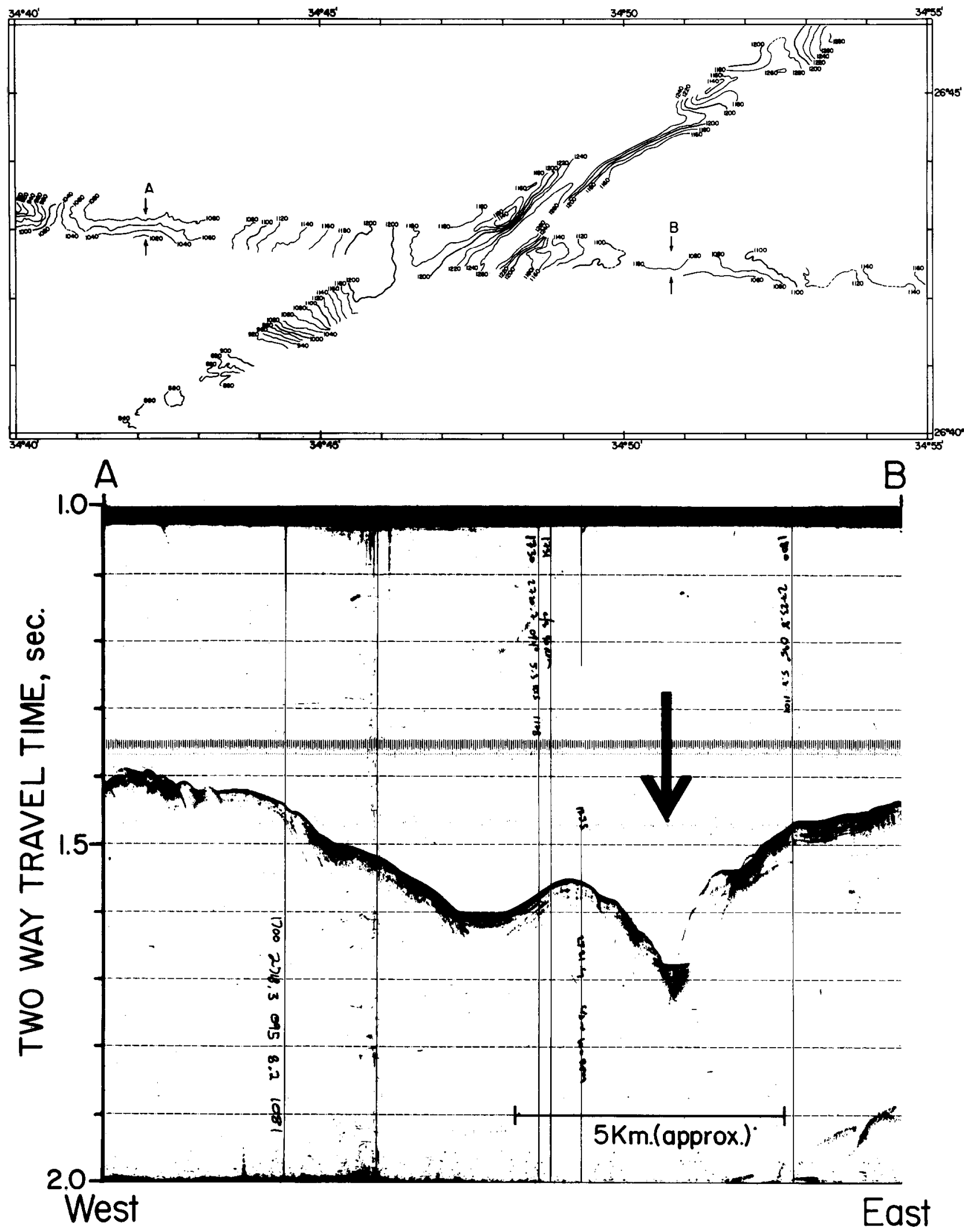

Fig. 6. Sea Beam swaths across central accommodation zone (top). The surface expression of the accommodation zone forms a narrow sinuous cleft approximately delimited by the $1200 \mathrm{~m}$ contour (uncorrected meters). Bottom shows $3.5 \mathrm{kHz}$ PDR profile crossing central accommodation zone. Narrow cleft indicated by bold arrow forms the surface expression of the accommodation zone. Section $A-B$ on profile is located by labeled arrows on the Sea Beam crossing (top). 
comes aligned with the Gulf of Suez (Fig. 4).

The main trough and axial depression are underlain by sedimentary sequences that include a thick evaporite layer of Middle to Late Miocene age (Whitmarsh et al., 1974). The top of this evaporite layer has been drilled and correlated (Whitmarsh et al., 1974) with a prominent seismic reflector referred to as reflector $\mathrm{S}$ (Phillips and Ross, 1970). A post-Miocene sedimentary sequence which overlies reflector $S$ is typically 0.2 to $0.3 \mathrm{~s}$ of two-way travel time thick near the central depression and generally slightly thickens landward towards the margins, although locally it can be much thicker (greater than 1 s).
Free-air gravity anomalies contoured at 10 $\mathrm{mGal}$ intervals are shown in Fig. 5. The northern Red Sea is generally characterized by negative free-air gravity anomalies with average values of about 0 to $-20 \mathrm{mGal}$ in the marginal areas and a consistent gravity low of from -30 to $-40 \mathrm{mGal}$ over the axial depression (Fig. 5). A "Y" shaped region of very low values with a minimum of -70 $\mathrm{mGal}$ is found near the juncture of the Red Sea with the Gulfs of Suez and Aqaba.

A series of elongate gravity highs sub-parallel to the overall Red Sea trend are located in the main trough outside the area of the axial depression. The gravity highs range from 0 to 20 or 30
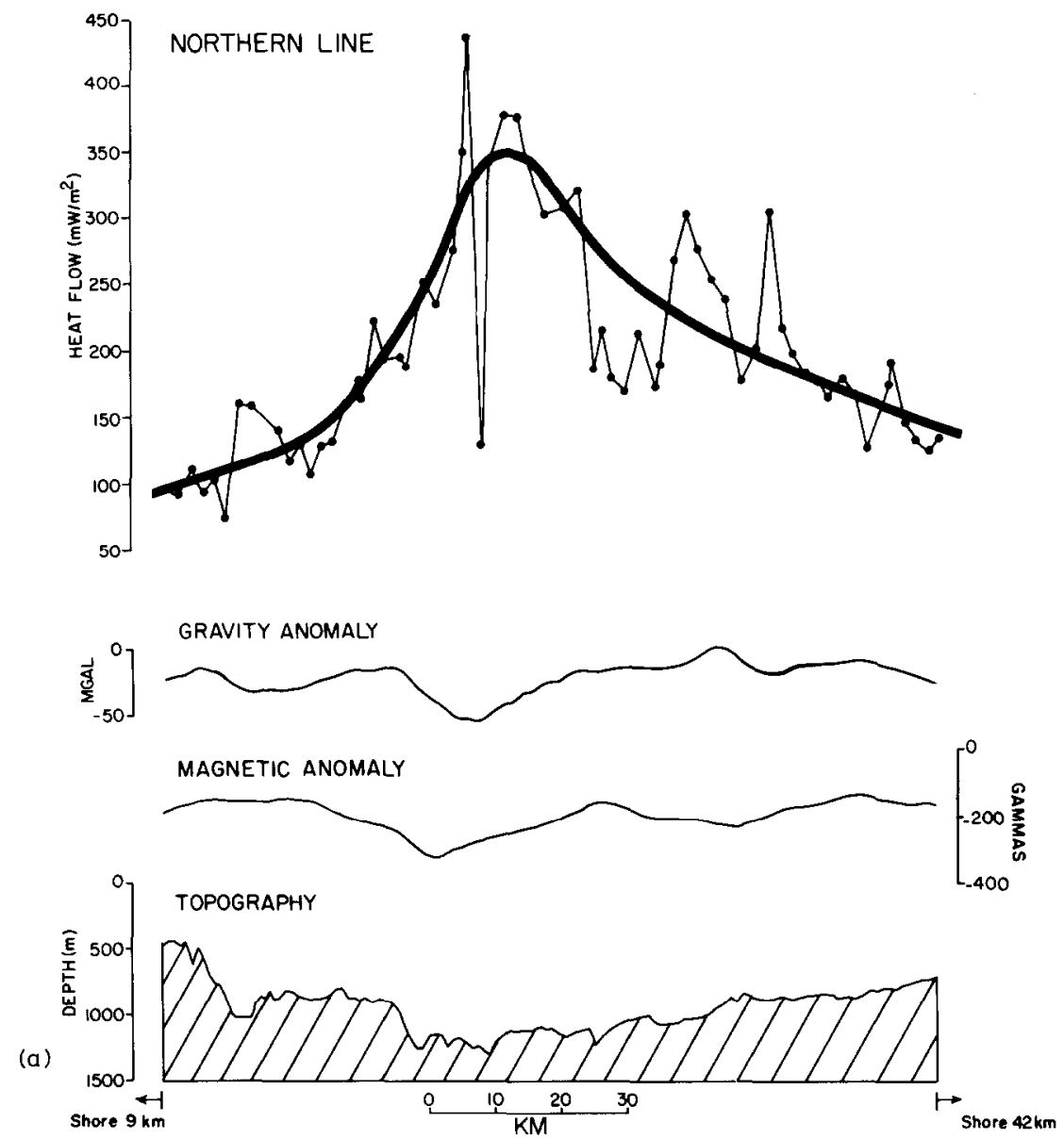

Fig. 7. Northern (a) and central (b) heat flow lines (see Fig. 2 for location) projected at N60 ${ }^{\circ}$. Topography, total intensity magnetics, and free-air gravity anomalies also shown at same projection. The heavy line in the heat flow profiles was fit by eye to indicate the overall trend in the data. Maximum heat flow values occur in the axial depression in both profiles. The axial depression corresponds to a region with depths greater than about $1100 \mathrm{~m}$. Note that the heat flow maximum is offset to the west in the northern line (a) to remain over the axial depression which is also offset to the west. 


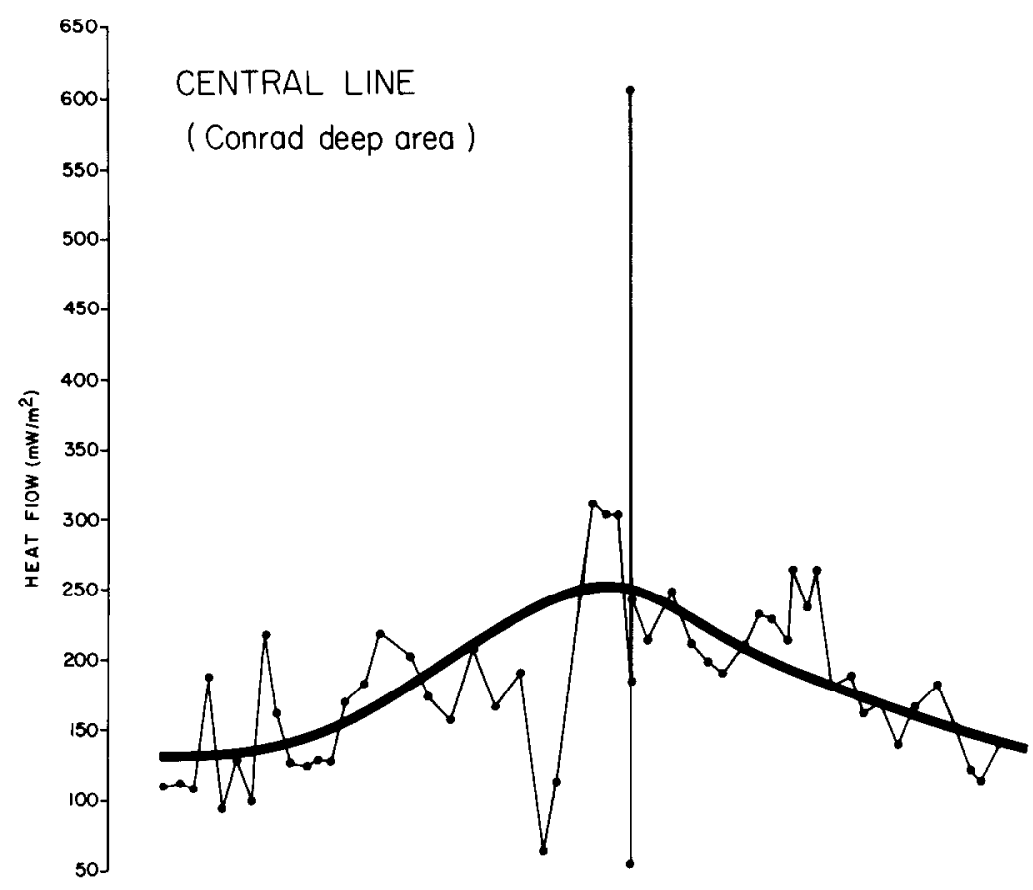

GRAVITY ANOMALY
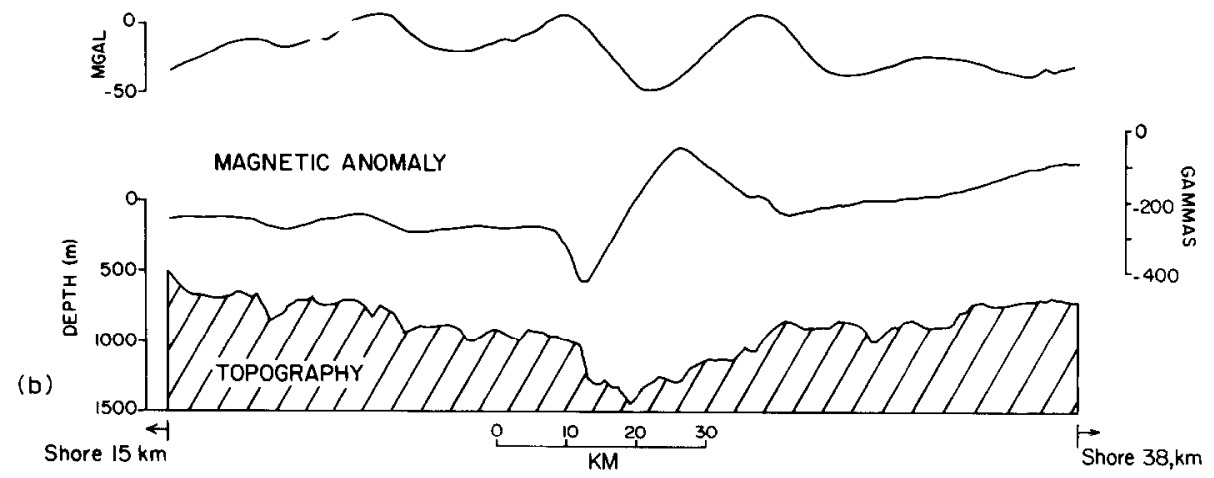

Fig. 7 (continued).

$\mathrm{mGal}$ and can be seen in the geophysical profiles (Fig. 3) to occur consistently over the seaward edges of the terraces. Systematic terminations or offsets of the pattern of gravity highs occur at intervals of 60 to $70 \mathrm{~km}$ along strike.

The boundaries that terminate or offset the pattern of gravity highs along strike coincide with transverse features that offset the bathymetric pattern. We have identified three of these transverse features in the northern Red Sea: a northern one which crosses the axial depression at $27.25^{\circ} \mathrm{N}$, $34.60^{\circ} \mathrm{E}$; a central one at $26.80^{\circ} \mathrm{N}, 34.95^{\circ} \mathrm{E}$; and a southern one at $26.36^{\circ} \mathrm{N}, 35.13^{\circ} \mathrm{E}$. All three have an azimuth of approximately $\mathrm{N} 60^{\circ} \mathrm{E}$ (see Fig. 4).

In a number of places the transverse features take the form of sinuous clefts. Figure 6 shows a Sea Beam map and the coinciding $3.5 \mathrm{kHz}$ profile of the central cross feature which is here 50 to 150 $\mathrm{m}$ deeper than the surrounding seafloor and is several hundred meters wide with an overall trend that varies from $040^{\circ}$ to $060^{\circ}$. We interpret the transverse features as the surface expression of accommodation zones across which sets of fault 
blocks are decoupled and have undergone differential displacements.

The bathymetric map (Fig. 4) shows that the axial depression is offset to the west by about 15 $\mathrm{km}$ across the northern accommodation zone so that while it is near the center of the sea south of this feature, to the north it is closer to the African coast. A continuation of the central accommodation zone toward the Arabian shore follows a distinct offset in the bathymetric contours to a 7 km offset in the coastline (Fig. 4). The southern accommodation zone can be extrapolated onto shore where it coincides with cross faults that truncate and offset tilted basement blocks of the Red Sea hills (Greene, 1984; M. Richardson, pers. commun., 1982). A similar pattern of tilted and faulted basement blocks cut by intervening cross faults has been mapped at several locations on land around the Red Sea (Schurmann, 1966; Garson and Krs, 1976).

Two of the heat flow profiles across the Red Sea are shown in fig. 7 and their location is indicated in Fig. 2. Generally high values characterize the rift and increase from about $100 \mathrm{~mW}$ $\mathrm{m}^{-2}$ near the margins to values of about $300 \mathrm{~mW}$ $\mathrm{m}^{-2}$ over the axial depression. The consistent association of the maximum heat flow values with the axial depression is shown by the fact that in the northern profile (Fig. 7a), where the axial depression is offset to the west, the heat flow high is also shifted to the west to be over it. Preliminary two-dimensional modeling of the effect of the topography and relief on the top surface of the more thermally conductive evaporites has shown (Hobart et al, 1985) that a significant amount of the scatter in the heat flow values can be attributed to these two causes.

\section{Marginal areas}

The marginal areas of the northern Red Sea vary from about 400 to $1100 \mathrm{~m}$ in depth. Narrow shelves surround the margins and average less than about $5 \mathrm{~km}$ in width on the western side but are generally wider than about $20 \mathrm{~km}$ on the eastern side. The marginal areas exhibit a variety of structures and styles of deformation. Figure 3 shows a series of geophysical profiles from north to south (see Fig. 2 for location) that have been stacked on the axial depression. Profile $A$, is located north of the northern accommodation zone and $B$ and $C$ intersect it. They show the blockier nature of the main trough to the west of the axial depression and the distinct escarpments that delimit the terraces. To the east of the axial depression the gradients are more gentle and consequently the terrace pattern less well defined giving the bathymetry the appearance of an irregular slope. A small graben can be seen approximately $10 \mathrm{~km}$ from the western end of profiles $B$ and C which are about $5 \mathrm{~km}$ apart at the location of the graben. In this distance the graben changes from about 3 to about $7 \mathrm{~km}$ in width. Seismic profile $6 \mathrm{a}$ (Fig. 8a), corresponding to geophysical profile B, shows that the graben contains about $0.4 \mathrm{~s}$ of post-evaporitic sediments and has a somewhat asymmetric shape, being deeper to the east. In seismic profile $6 \mathrm{~b}$ (Fig. $8 \mathrm{~b}$ ) only about $1 \mathrm{~km}$ to the south, the graben has increased in width from 3 $\mathrm{km}$ to $3.5 \mathrm{~km}$, deepened to $0.54 \mathrm{~s}$ and has become more symmetric. The layering of the sediments within this graben abruptly terminate against the walls of the graben in a manner which is distinct from the more gently onlapping configuration of the synforms associated with diapir growth, an example of which can be seen in the same profile (Fig. 8a) about $10 \mathrm{~km}$ east of the graben. Such synforms or "rim synclines" are known to be associated with diapirs and physical modeling (Lemon, 1985) and detailed facies studies (Seni and Jackson, 1983) indicate that they result in part from syndepositional processes that occur during diapir growth.

Profiles $D$ through $G$ are located between the northern and central accommodation zones. Here the axial depression is more centrally located and the margins have a more symmetric appearance. Figure 9 shows a seismic line corresponding with profile $F$ with another small graben which can also be seen near the western ends of profiles $E$ through $\mathrm{G}$ which span about $20 \mathrm{~km}$ along strike. This graben offsets the seafloor by about $0.20 \mathrm{~s}$ and several small offsets of the seafloor of less than about $0.05 \mathrm{~s}$ can be seen on either side (Fig. 9). These offsets in the seafloor occur over what appear to be diapirs flanking the graben. The 


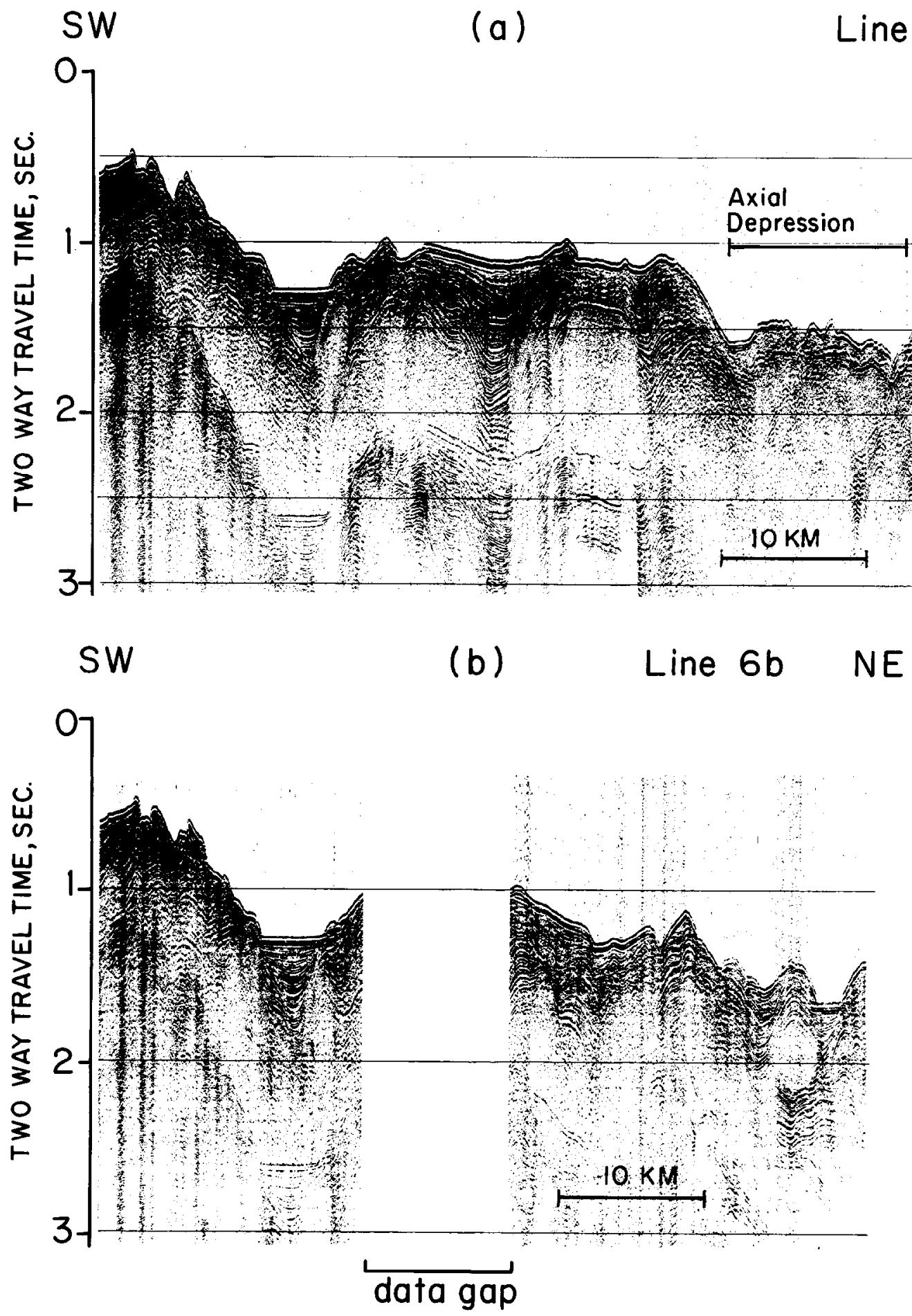

Fig. 8. Single channel watergun seismic profiles 6a (a) and 6b (b) (see Fig. 2 for location). A small graben can be seen approximately $14 \mathrm{~km}$ from the southwest end of both profiles. More intense deformation associated with axial depression is evident in (a). Reflector $S$ is labeled. 


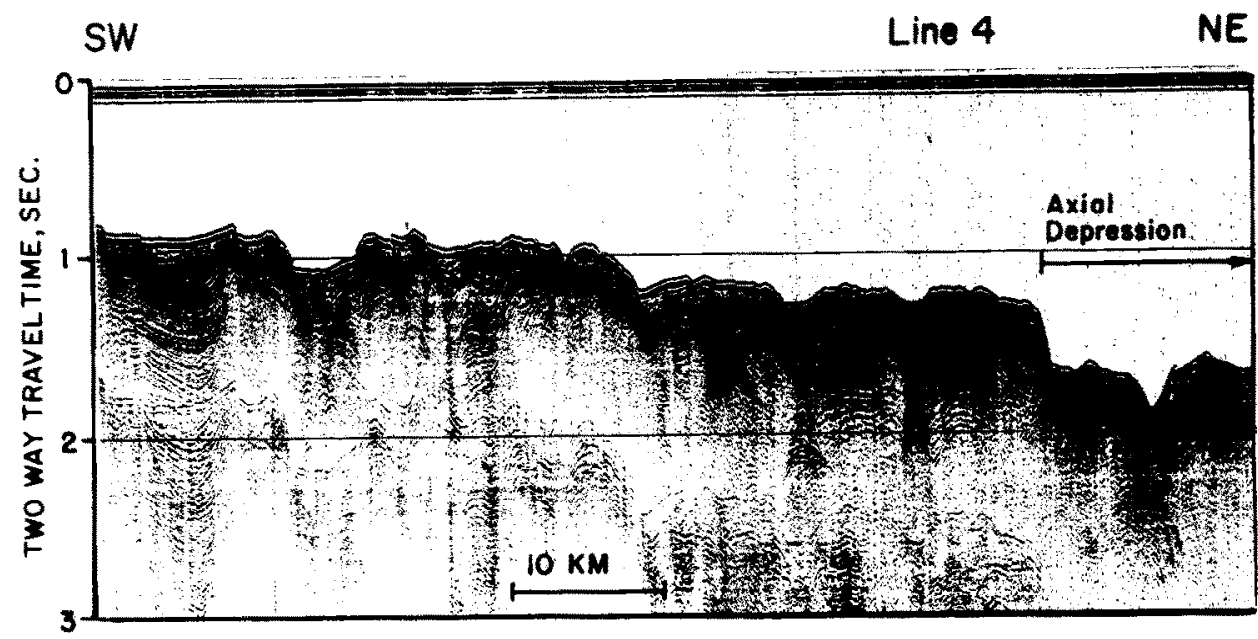

Fig. 9. Single channel watergun seismic line 4 (see Fig. 2 for location). Small graben with flanking diapirs can be seen about $15 \mathrm{~km}$ from southwest end of profile. Note step-like terraces dropping down toward the axial depression which is fault-bounded in this line. The narrow deeper zone in the axial depression is the Conrad Deep.

diapiric structure to the west of the graben is more developed and has an asymmetric synform associated with it containing discordant packets of sediments suggesting episodic movements of the diapir.

Many of the diapirs shown in our seismic lines are associated with tectonic structures such as the grabens and major faults which affect the seafloor and form steep bathymetric gradients (Figs. 10 and 11). It thus seems likely that diapirism initiated in many cases as a consequence of tectonic disturbances.

The scismic character of the evaporites varies within the marginal areas of the main trough. Reflector S, which has been shown to correlate with the top of the evaporites (Whitmarsh et al., 1974), has a relatively uniform character typically appearing as a strong double reflector or series of reflectors, however, in places it may become irregular or indistinct, particularly over the diapirs or in the rim synclines surrounding them where the overlaying sediments are strongly layered. A hole drilled at DSDP site 228 in the southern Red Sea (Whitmarsh et al., 1974) encountered the top of the evaporite sequence adjacent to a small diapir where reflector $\mathbf{S}$ appeared weaker than at adjacent areas that were less disturbed. Cores recovered from this site showed the top of reflector $\mathrm{S}$ to correspond with a brecciated anhydrite layer, in contrast to other sites $(225,227)$ where the reflector is better defined and the cores recovered showed reflector $\mathrm{S}$ to be correlated with nodular to laminar anhydrite. In all cases the anhydrite layer separated the Miocene evaporite sequence from the post-Miocene sediments.

Reflectors below S vary from strongly layered to unlayered or chaotic. In places where the sub-S reflectors are layered, they are generally conformably parallel $S$, as can be seen in several locations in the seismic line of Fig. 10 located just south of the northeast corner of the Red Sea. This appears to be an area that is relatively less deformed forming long wavelength folds between the diapirs. In the more deformed areas near large bathymetric gradients or in diapiric structures sub-S arrivals are typically unlayered. This observation suggests that deformation associated with diapirism or with faulting tends to obliterate seismic layering within the evaporites.

The reflectors above $S$ have a variety of stratigraphic relations with $S$. Locally the whole sedimentary sequence from $S$ to the seafloor may appear conformable with reflector $S$, even where $S$ is mildly folded (e.g., eastern end of seismic line in Fig. 8a), but these areas are rare and of limited extent on the margins. As will be discussed in more detail later, a conformable relation between $\mathrm{S}$ and reflectors above it is more prevalent in the 


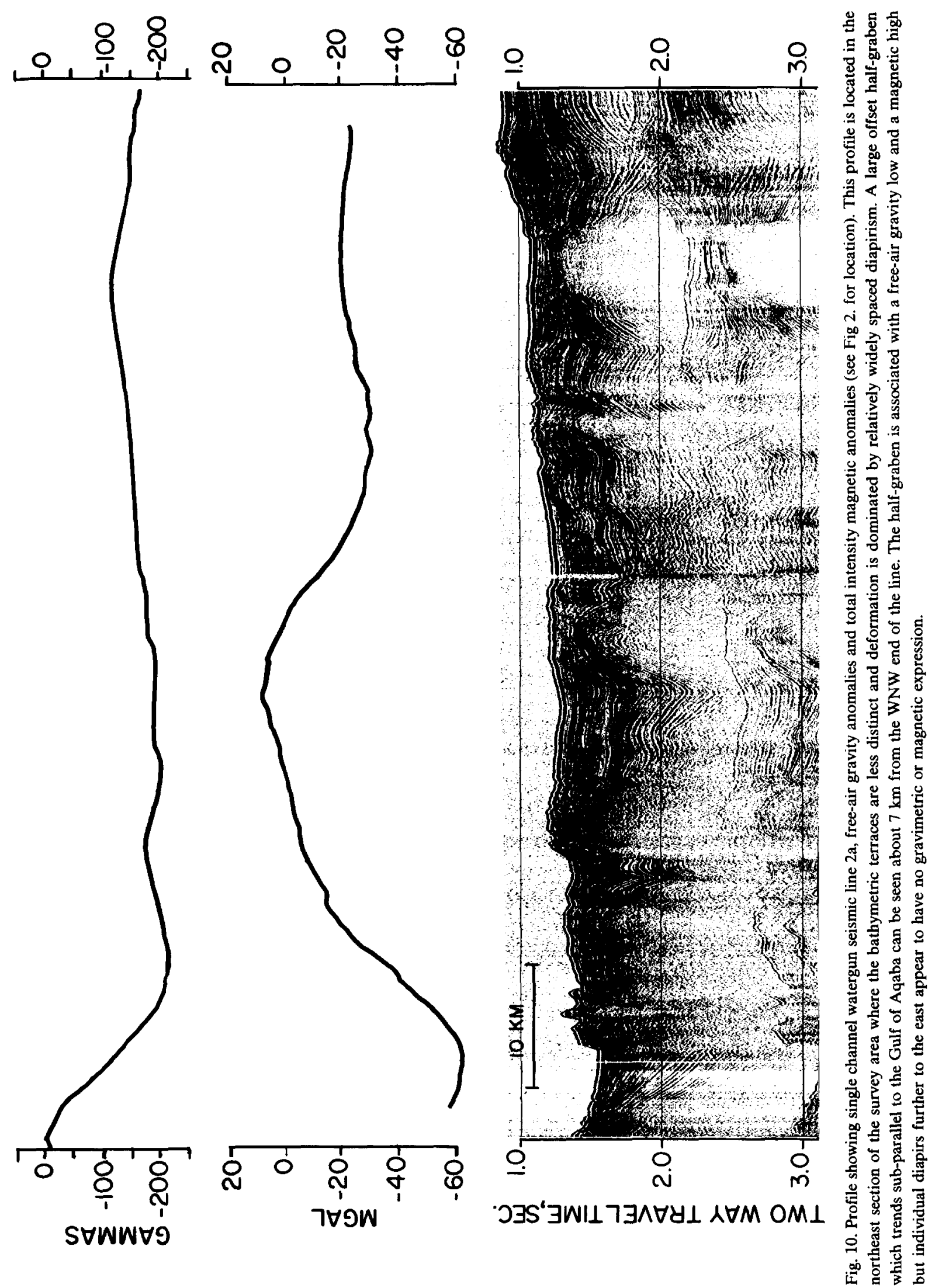


axial depression. In contrast to these few areas, most of our profiles across the marginal areas show a blanketing effect of the post $-S$ layers with marked discordances in many places (see Figs. 8-11). Seismic profiles generally show a decrease in deformation from reflector $\mathrm{S}$ to the seafloor with individual reflectors frequently having onlapping terminations on lower ones. These relationships indicate episodic tectonic activity in the marginal areas and less intense recent deformation

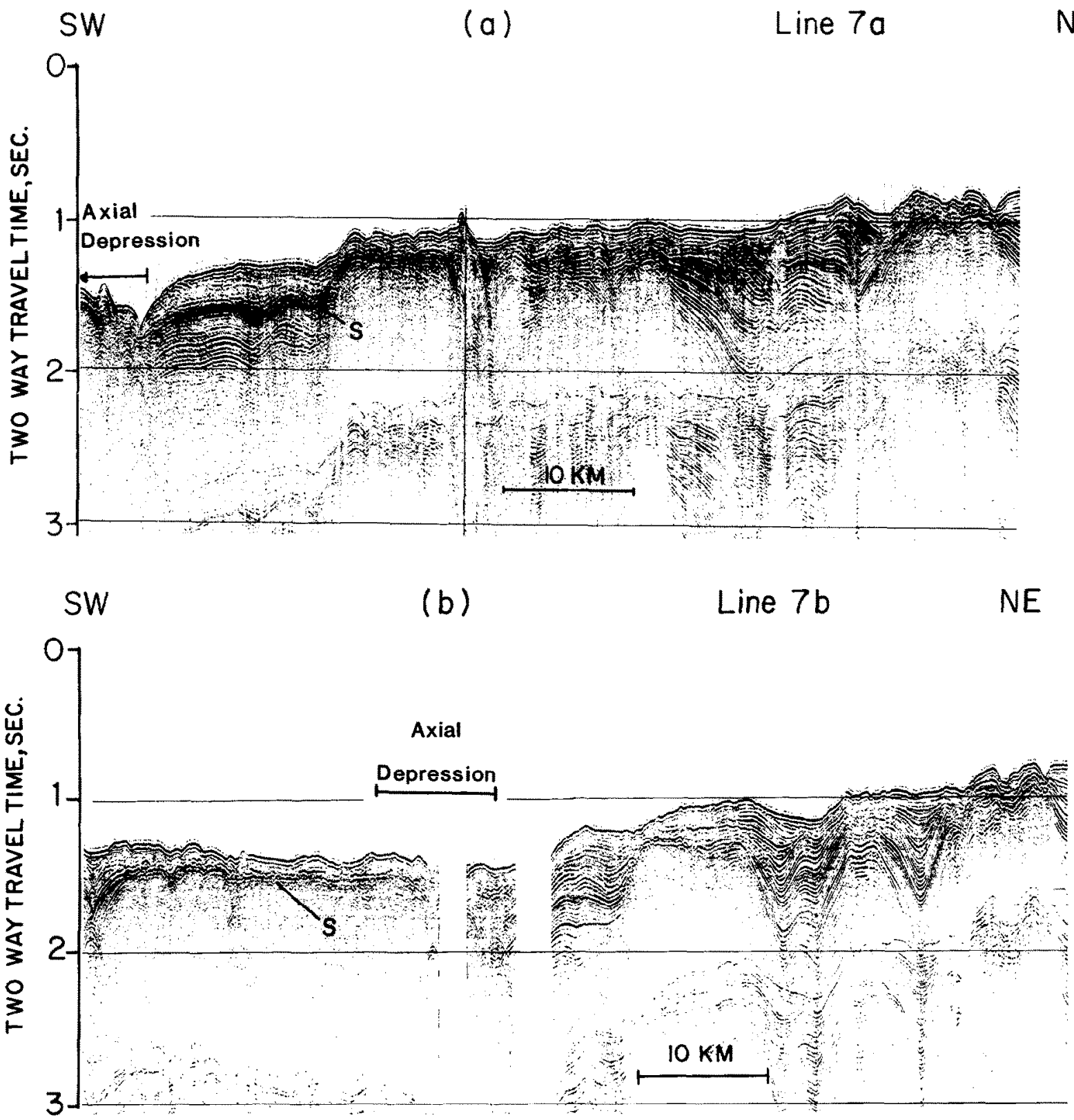

Fig. 11. Watergun seismic line $7 a$ (a) and $7 b$ (b) (see Fig. 2 for location). The lines diverge at an angle of about $13^{\circ}$ from the northeast end. The crest of a diapir visible near the northeast end of both lines appears to have collapse features affecting the seafloor. Further to the southwest well developed "rim synclines" can be seen on either side of diapiric structures in (b) overlaid by a less deformed layer containing discordant packets of sediments. Layering is generally not apparent in diapirs although in less disturbed areas sediments can appear layered below reflector $S$ (labeled " $S$ ") as can be seen in the area immediately northeast of the axial depression in (a). 


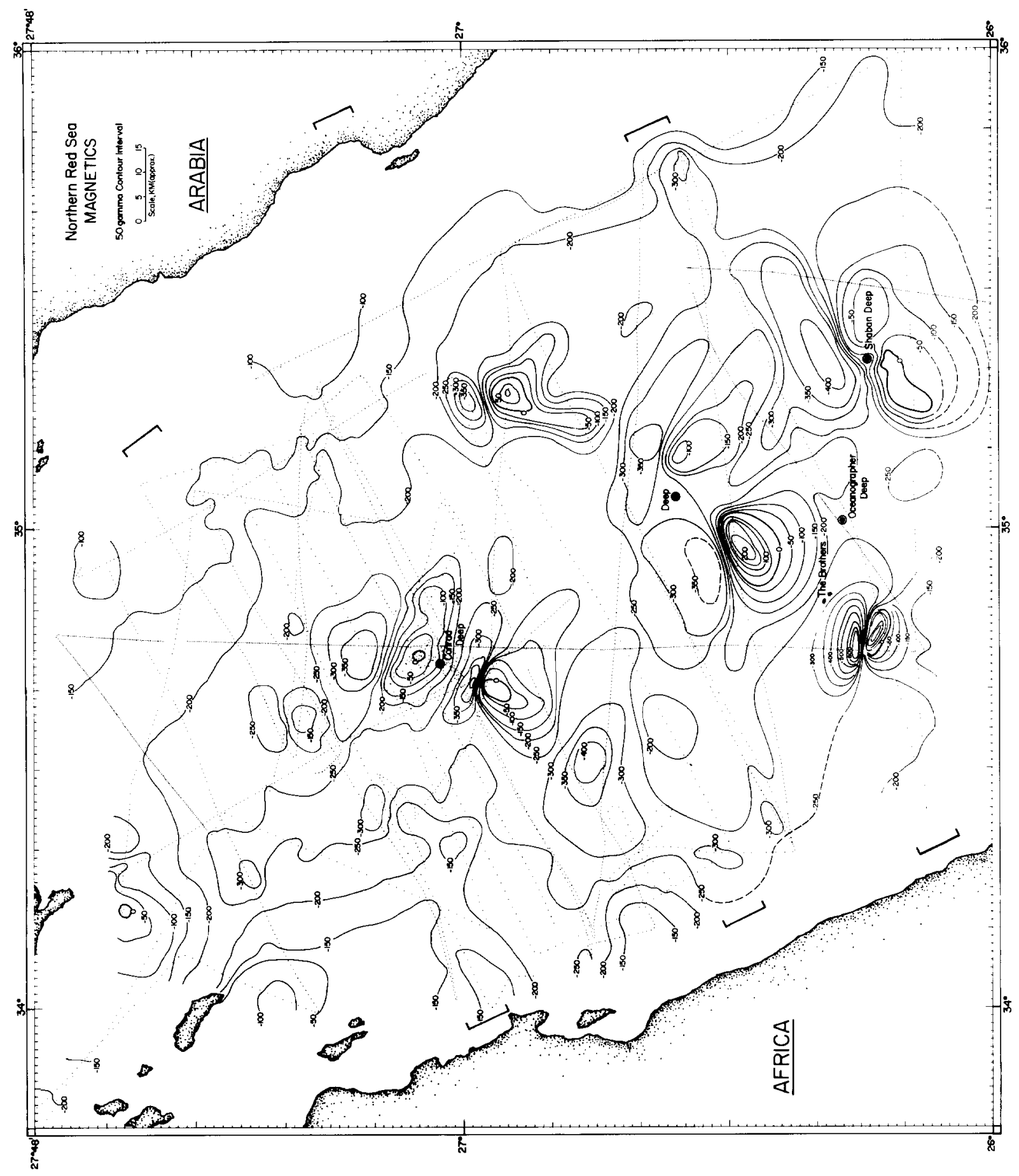

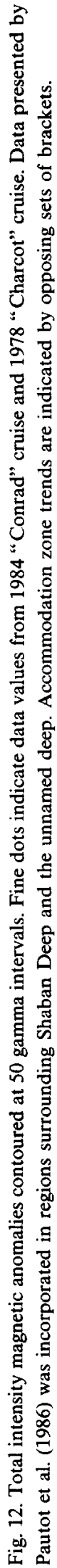


than at areas where the sediments are conformably deformed to the seafloor.

Magnetic anomaly profiles across the rift are shown in Fig. 3 and a contour map of the anomalies in the northern Red Sea is shown in Fig. 12. The profiles show low amplitude long wavelength anomalies that generally become more negative toward the center of the main trough near the axial depression. The high amplitude shorter wavelength anomalies evident on some profiles (Fig. 3) can be seen on the contour map (Fig. 12) to result from localized dipolar anomalies. The magnetic field of the northern Red Sea thus appears to result from isolated magnetic sources in a relatively less magnetic medium. No lineated magnetic anomalies which might reflect the presence of seafloor spreading are present. All of the dipolar anomalies mapped are consistent with a predominantly normal magnetization. Two of the dipolar anomalies occur in the marginal areas, a southwestern one at $26^{\circ} 15^{\prime} \mathrm{N}, 34^{\circ} 45^{\prime} \mathrm{E}$, and an eastern one at $26^{\circ} 57^{\prime} \mathrm{N}, 35^{\circ} 15^{\prime} \mathrm{E}$. Both occur at the intersection of escarpments bounding the marginal terraces with the cross cutting accommodation zones. A $20 \mathrm{mGal}$ gravity anomaly (see Fig. 5) coincides with the southwestern dipole and an Exxon multichannel seismic reflection line (Fig. 13) reveals the presence of a bathymetric edifice with a relief of $0.5 \mathrm{~s}$ piercing through the sedimentary cover at the same location. The other dipolar anomalies are located in the axial depression and appear to be associated with deeps (Cochran et al., 1986; Pautot et al., 1984, 1986).

Profiles of the free-air gravity anomaly field of the marginal areas are shown in Fig. 2 and the anomalies are contoured at $10 \mathrm{mGal}$ intervals in Fig. 5. A pattern of elongate gravity highs and lows trends subparallel to the strike of the bathymetric terraces (see Figs. 5 and 4). Gravity profiles (Fig. 3) show that maximum anomalies occur near the seaward edges of the terraces. A two-dimensional gravity model was carried out in order to

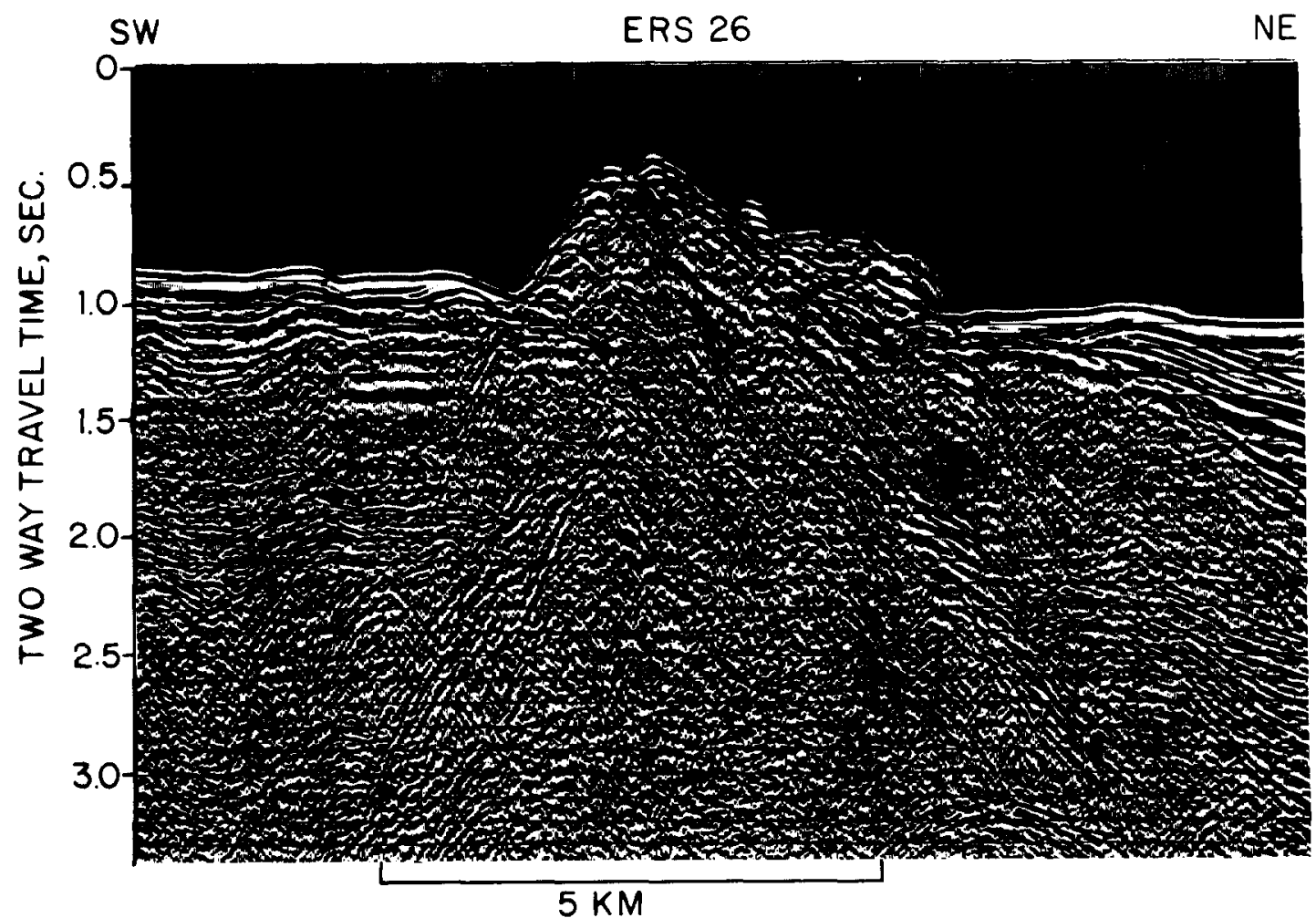

Fig. 13. Section of Exxon multichannel seismic line ERS26 crossing a bathymetric edifice located approximately $10 \mathrm{~km}$ southwest of the Brothers Islands (see Fig. 2 for location). This feature is associated with a large dipolar magnetic anomaly (see Fig. 12) and a free-air gravity anomaly (see Fig. 5) and occurs at the intersection of the southern accommodation zone with the edge of a bathymetric terrace. 
investigate whether the relief on the sedimentary layers is sufficient to account for the amplitude of the observed anomalies. An Exxon 48 channel seismic reflection line which lies coincident with one of our shiptracks was digitized for seafloor, top of evaporites and bottom of evaporites following the interpretation of Barakat and Miller (1984). The bottom of the evaporites was the deepest reflector which they could resolve, although not continuously. The digitized horizons were converted from time to depth using constant velocities within layers that were consistent with nearby well data (Barakat and Miller, 1984) and previous refraction work (Drake and Girdler, 1964). Typical densities (M. Steckler, pers. commun., 1986)

\section{Free-air Gravity Anomalies}

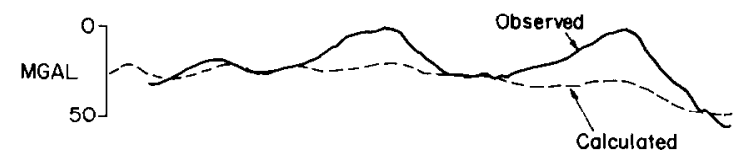

Stratigraphic Section

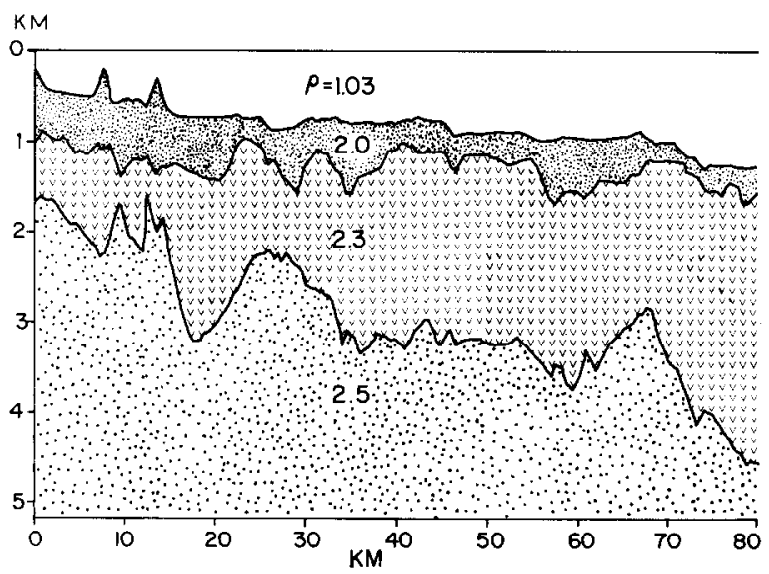

Fig. 14. Gravity model comparing observed gravity anomalies (solid line) to the 2-D calculated gravity effect (dashed line) of water column (blank), post-evaporite sediments (fine stipple), evaporites ( $v$ pattern) and pre-evaporite sediments (coarse stipple). A flat bottom was assumed for the pre-evaporite boundary with the basement and an arbitrary constant was added to superimpose profiles. Failure of calculated gravity anomalies to match the observed variations suggests that the observed anomalies result from large-scale relief on the basement-preevaporite boundary. Interpretation of Exxon MCS line generally follows Barakat and Miller (1984). The observed gravity line is from the 1984 "Conrad" cruise coincident with Exxon MCS line. were assigned to the layers and the $2-\mathrm{D}$ gravity effect was calculated using the method of Talwani et al. (1959) assuming a flat bottom to the preevaporite layer. The results are shown in Fig. 14. As can be seen, the calculated gravity effect from the stratigraphy is insufficient to account for the observed gravity anomalies. This suggests that the gravity pattern results primarily from large-scale relief on a deeper layer, which we infer to be tilted fault blocks of the basement. The basement structures of the marginal areas thus appear from the bathymetry and gravity data to be a series of tilted fault blocks 20 to $30 \mathrm{~km}$ across and roughly $60 \mathrm{~km}$ in length partitioned along strike by intervening accommodation zones. The pattern of bathymetric terraces thus appears to be a subdued expression of this basement structure.

\section{Axial depression}

The area which we refer to as the axial depression is a region of deeper water 1100 to $1300 \mathrm{~m}$ deep and generally from 10 to about $25 \mathrm{~km}$ wide. It forms a continuous zone that extends from and is aligned with the entrance to the Gulf of Suez in the north and about $50 \mathrm{~km}$ to the south of the Gulf becomes more centrally located and continues to the southern part of the survey area near $26^{\circ} \mathrm{N}$ latitude.

Knott et al. (1965) describe “a deep axial zone of rugged floor and intense sub-bottom deformation and shallower marginal zones of more gentle topography and milder deformation, which bound the axial zone to the east and west" in the northern Red Sea. They also noted that there were abrupt transitions from the "marginal zones" to the "axial zones" in places which appear on their seismic profiles as escarpments that offset not only the seafloor but also reflector $\mathrm{S}$ by several hundred meters. Their "axial zone", however, includes an area that is somewhat wider than the "axial depression" described here.

Our seismic lines (Figs. 9 and 15) reveal that short wavelength folding and faulting is prevalent in the axial depression. The seismic lines in Fig. 15 show that reflector $S$ appears folded and faulted in the axial depression but layers above $S$ are more conformable with $S$ in the axial depression 


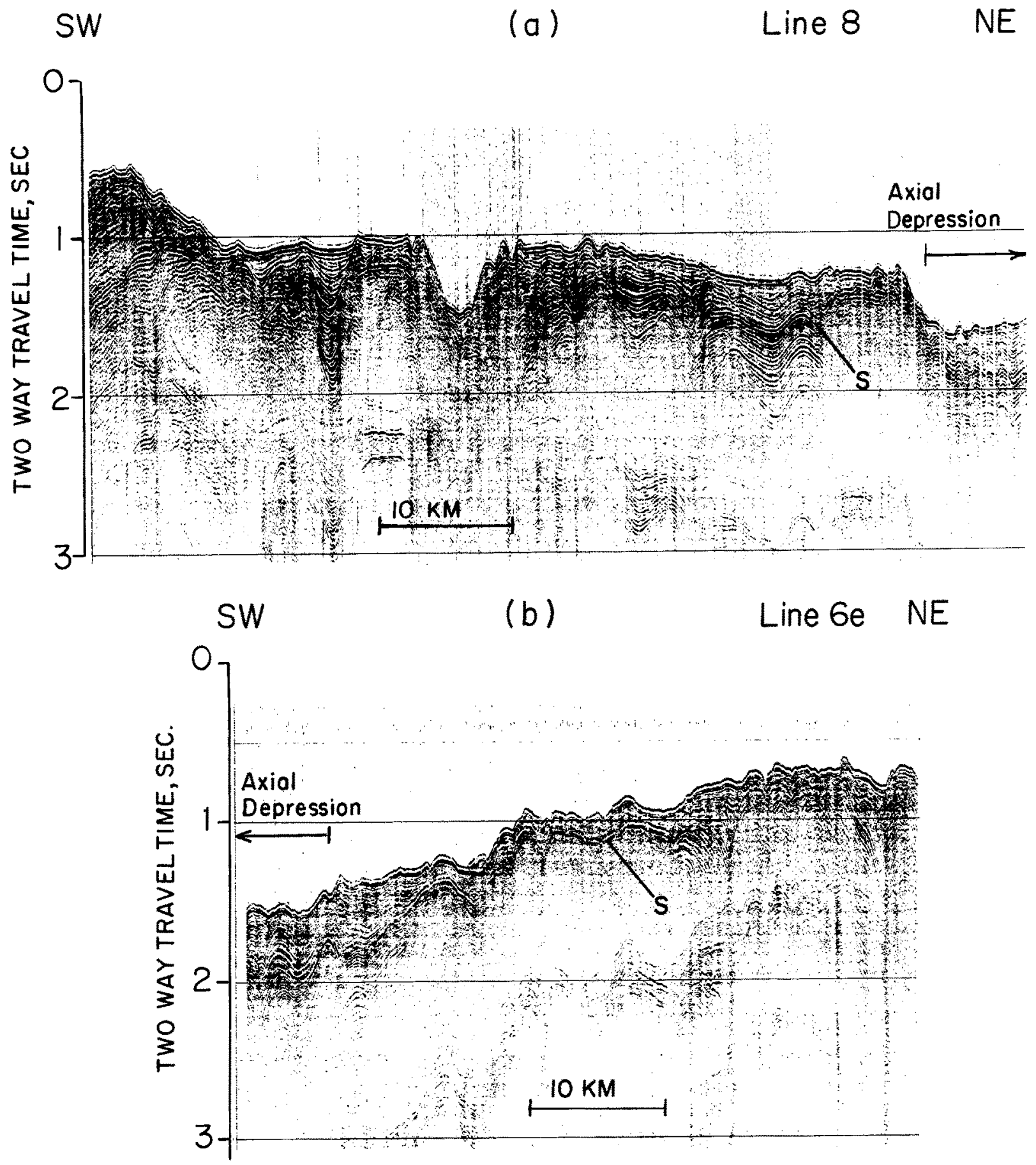

Fig. 15. Seismic lines 8 (a) and $6 \mathrm{e}$ (b) across marginal areas and axial depression (see Fig. 2 for location). A gap of approximately 9.5 $\mathrm{km}$ exists between the northeast end of line 8 and southwest end of line $6 \mathrm{e}$. The axial depression contains closely spaced deformation which affects the entire sedimentary sequence to the seafloor. Marginal areas on either side of the axial depression have more widely spaced deformation which is in many places associated with diapirism. Sediments in the marginal areas generally exhibit a more pronounced decrease in deformation toward the seafloor than in the axial depression, with locally discordant packets occurring in places. The narrow graben which occurs $28 \mathrm{~km}$ from southwest end of line 8 (a) offsets the latest sediments and indicates that the marginal areas are tectonically active in places. Reflector $S$ is labeled " $S$ ". 
than on the marginal areas. Frequently the seafloor is also deformed conformably with $\mathrm{S}$ with only minor discordances near the very top indicating that the deformation in the axial depression is recently active and that it has not been abating with time. The boundary between the axial depression and the marginal areas often takes the form of steep escarpments offsetting the seafloor and reflector $S$ by up to about $300 \mathrm{~m}$ (Fig. 9). Diapiric structures are sometimes found on the marginal side of these escarpments (see Fig. 8a).

Daggett et al. (1986), using a local network in Egypt, report a total of five earthquakes occurring in the Red Sea median zone north of $25^{\circ} 45^{\prime} \mathrm{N}$, which they tentatively interpret as defining an active tectonic zone. These earthquakes all occur within the axial depression. Their data and published International Seismologic Centre (ISC) data record almost no earthquake activity in the marginal areas of the northern Red Sea away from the Gulf of Suez area except for a cluster of microearthquake activity on land in Egypt. In 1982, a magnitude 4.8 earthquake occurred in the axial depression at $26.8^{\circ} \mathrm{N}, 34.82^{\circ} \mathrm{E}$ (ISC, 1982), near the central accommodation zone. Daggett et al. (1986) report a 1980 earthquake with a magnitude between 2 and 3 at about the same location. The pattern of seismicity is consistent with our seismic profiles and other data which indicate more intense deformation in the axial depression suggesting that it is an active tectonic zone and that the marginal areas are comparatively less active.

Recently a series of small deeps have been identified in the axial depression of the northern Red Sea (Pautot, 1983; Pautot et al., 1984, 1986; Cochran et al., 1986). These deeps are generally 150 to $200 \mathrm{~m}$ deeper than the surrounding floor of the axial depression which is at 1200 to $1300 \mathrm{~m}$, are several tens of square kilometers in area and have a variety of shapes and orientations. Some of these deeps are associated with large dipolar magnetic anomalies. The two most studied are Shaban (or Jean Charcot) Deep and Conrad Decp. Shaban Deep has a large dipolar magnetic anomaly, brine layers, and a ridge in its center from which a basalt fragment has been recovered (Pautot et al., 1984). Conrad Deep has two dipolar magnetic anomalies associated with it and an extremely variable heat flow indicating active hydrothermal circulation (Cochran et al., 1986). Evidence indicates that both deeps result from recent intrusions. In addition, an unnamed deep located in the axial depression at $26^{\circ} 36^{\prime} \mathrm{N}, 34^{\circ} 04^{\prime} \mathrm{E}$ can be identified on Sea Beam data presented by Pautot et al. (1986). This deep has a floor at somewhat greater depth than $1500 \mathrm{~m}$. Combining our magnetic data with that presented by Pautot et al. (1986) in this region indicates that the unnamed deep is associated with a pair of dipolar anomalies (Fig. 12) located near the bathymetric edges of the axial depression (Fig. 4) in a manner similar to that of the anomalies observed surrounding Conrad Deep. In addition to being located in the axial depression, these three deeps are spaced at a separation of from 50 to $60 \mathrm{~km}$ from each other and each is situated midway between sets of accommodation zones. Other isolated depressions which can be identified in our bathymetric map (Fig. 4) and in data presented by Pautot et al. (1986) appear not to be associated with magnetic anomalies suggesting that they are not related to intrusions.

\section{Northern termination of the axial depression and juncture with the Gulf of Suez and the Gulf of Aqaba}

The axial depression is offset across the northern accommodation zone so that to the north it is located roughly $50 \mathrm{~km}$ from the African coast but more than $110 \mathrm{~km}$ from the Arabian coast. South of the accommodation zone the axial depression is more centrally located, generally occurring between 80 and $100 \mathrm{~km}$ from the African coast and between 90 and $100 \mathrm{~km}$ for the Arabian coast. The shift of the axial depression toward the west, north of the accommodation zone, places it in alignment with the mouth of the Gulf of Suez.

No deep clearly associated with intrusions has been located in this northern segment of the axial depression. An oval shaped depression about 1500 $m$ deep is apparent on both our data and that of Pautot et al. (1986) near $27^{\circ} 18^{\prime} \mathrm{N}, 34^{\circ} 22^{\prime} \mathrm{E}$, but it is not associated with a magnetic anomaly.

The trend of the axial depression is maintained in a NW direction throughout the survey area including this northernmost part, although the 
trend of many of the smaller structural features undergo many local irregularities and significant variations. Much of the local variation in trend and irregular bathymetry appears to be related to the numerous smaller diapirs that deform the seafloor. A series of these diapirs is evident in the seismic line shown in Fig. 10. The features associated with the diapirs can change appreciably over a few kilometers along strike as shown in Figs. 8a, $8 \mathrm{~b}$ and $11 \mathrm{a}, 11 \mathrm{~b}$ and in fact, many of the diapirs seem to have limited along strike extent.

Mart and Hall (1984) and Mart and Rabinowitz (1986) interpret seismic reflection profiles of the northern Red Sea as indicating a pattern of rifts and diapirs that systematically change trend in an arcuate manner from NNW-SSE near $27^{\circ} \mathrm{N}$ to N-S toward the north and then to NNE-SSW along the southeast margin of the Sinai peninsula. Their interpretation is based on assuming continuity between what they see as active and inactive segments of the same fault expressed as diapiric and synformal reflectors on their interpreted seismic sections (Mart and Hall, 1984; Mart and Rabinowitz, 1986). However, our data and the interpretation of seismic reflection data by Uchupi and Ross (1986) indicate that these features may not be as continuous as Mart and Hall (1984) and Mart and Rabinowitz (1986) suggest. Our seismic reflection data suggests that many of the "rifts" identified by Mart and Hall (1984) and Mart and Rabinowitz (1986) may actually be "rim synclines" related to the evolution of the diapirs. In addition, the main bathymetric pattern and free-air anomaly pattern (Figs. 4 and 5) continue the north-northwest, rift-parallel trend and do not show evidence of the progressive change in trend described by Mart and Hall (1984) and Mart and Rabinowitz (1986). A few elongate bathymetric highs and lows with trends varying from NNE-SSW to NE-SW are present near the deeps in the axial depression but these are small features with limited continuity.

The axial depression is terminated in the north by a NNE-trending high extending from Shadwan Island toward the southwestern margin of Sinai. This high forms the edge of a half graben structure with beds having a component of dip to the northwest and has been interpreted as overlaying a tilted block (Pautot et al., 1986). This structure is bounded on the northwest by a steep escarpment which then passes into the shallow water of the Gulf of Suez.

The axial depression deepens slightly at the northern end reaching depths greater than $1200 \mathrm{~m}$ south of Ras Muhammad. This area coincides with the center of a "Y" shaped gravity low with minimum values of $-70 \mathrm{mGal}$. The northeast branch of this gravity low trends in the direction of the Gulf of Aqaba and coincides with an elongate escarpment trending $\mathrm{N}_{23^{\circ}}$ and having a relief of $100 \mathrm{~m}$ shown in the Sea Beam map of Fig. 16. Figure 16 also shows a detail of the northwestern end of the seismic profile shown in Fig. 10 where it crosses the escarpment. The escarpment forms the trace of the boundary fault of a major half graben containing over $1 \mathrm{~s}$ of post-evaporite sedimentary fill which dips toward the east-southeast. The layering in reflectors in the half graben suggests a generally continuous tilting of the graben for the lowermost sediments, producing a smoothly onlapping pattern with perhaps more episodic motion in the upper 0.1 or $0.2 \mathrm{~s}$ forming slightly more discordant packets of sediments.

The asymmetric pattern of the half-graben is quite pronounced and distinct from other graben structures that have been seismically profiled in the northern Red Sea which tend to be more symmetric (Figs. 8a, 8b and 9). This half-graben structure is similar, however, to that of a series of deeps in the Gulf of Aqaba which have been seismically profiled showing that they are underlain by an asymmetric sequence of tilted reflectors (Ben-Avraham, 1985). This sequence of deeps has been interpreted to result from strike-slip with a component of opening on faults bounding the deeps forming asymmetric rhomb-shaped halfgraben which continue in an en echelon geometry south along the axis of the Gulf of Aqaba and into the Red Sea (Ben-Avraham, 1985). The escarpment is in line with this series of deeps and it appears that the half graben south of Ras Muhammad is a continuation of this structural pattern.

This escarpment and half graben (Fig. 16) therefore appears to be the expression of the Aqaba-Dead Sea "leaky" transform which intersects the Red Sea and Gulf of Suez rifts at the 


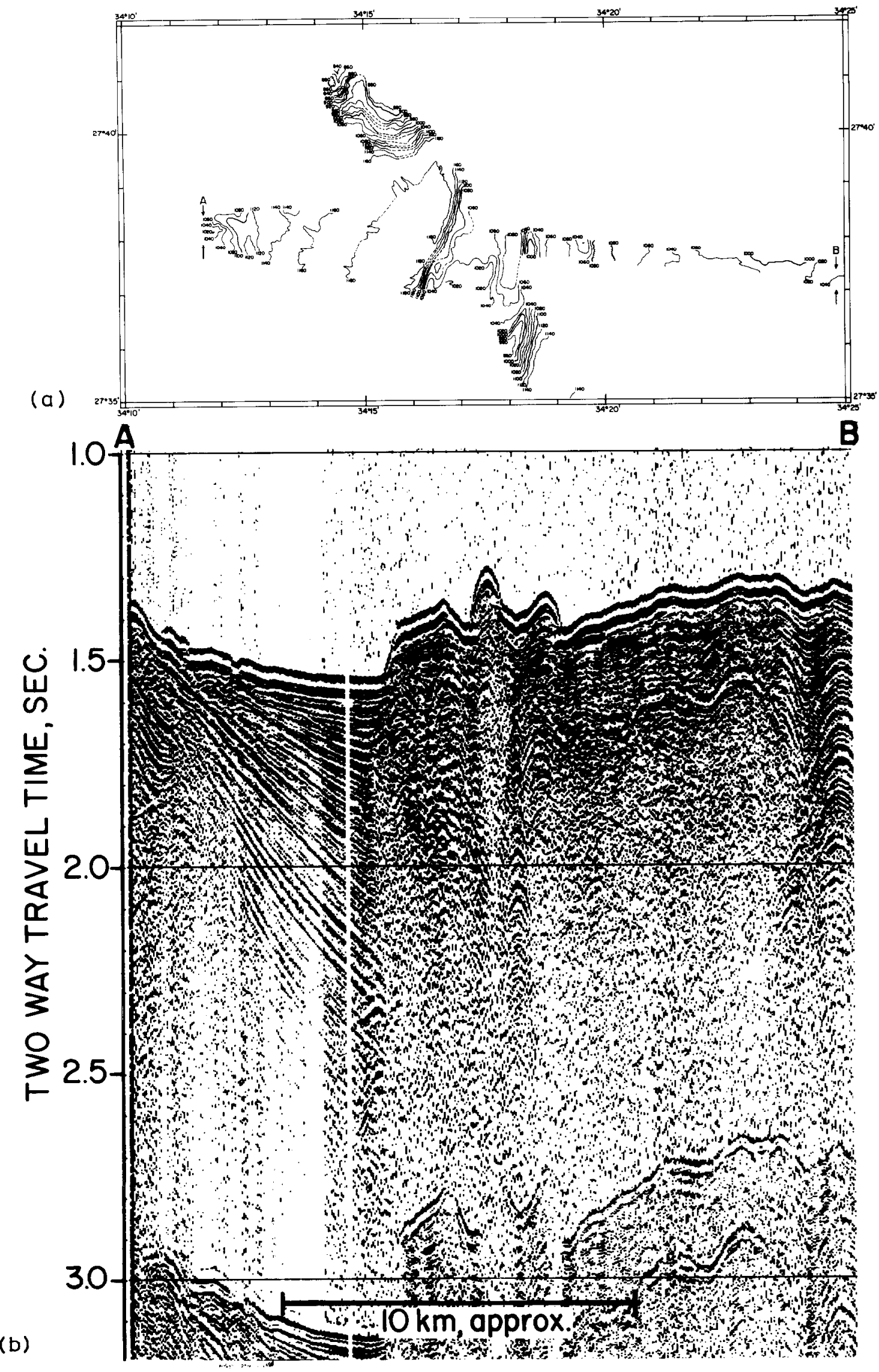


deep area south of Ras Muhammad and is well developed and well defined right up to this intersection. This structure apparently also forms a boundary between a region of scattered seismicity north of the mouth of the Gulf of Suez and the less seismically active area of the Red Sea immediately to the south. Thus to the extent that the Gulf of Suez is still opening the gravity low represents the location of the continental equivalent of a RRT triple juncture.

\section{Discussion}

The northern Red Sea is a continental rift that has developed nearly to a point of initiation of seafloor spreading. Two distinct provinces having different structural and geophysical characteristics have been identified within the "main trough" of the northern Red Sea which we refer to as the "marginal areas" and the "axial depression". The geophysical data imply that the marginal areas are underlain by faulted and tilted basement blocks which have considerable along strike continuity with major terminations occurring, however, along cross cutting "accommodation zones" that serve to take up differential displacements between sets of fault blocks. The accommodation zones are spaced roughly $60 \mathrm{~km}$ apart and are oriented approximately perpendicular to the main trend of the rift and to individual fault blocks. This basement structure is very similar to that observed at sediment starved margins, such as in the Bay of Biscay (Montadert et al., 1979), so that it appears that the basement structure of the marginal areas of the northern Red Sea is typical of that associated with "Atlantic type" passive margins. With due caution therefore, a model for the development of the northern Red Sea and the transition from continental rifting to seafloor spreading may be applicable to the development of older passive margins elsewhere, in particular to those known to have had an extended rifting phase. Extension rates in the northern Red Sea are slow $(0.9 \mathrm{~cm} / \mathrm{yr}$ total rate) compared to most areas of seafloor spreading. However, the extended periods of rifting observed at many Atlantic type margins (Jansa et al., 1980; Cande and Mutter, 1982) suggests that slow extension may be characteristic of many rifted margins.

Seismic reflection profiles of the evaporites and overlaying sediments in the marginal areas show that they are affected by relatively widely spaced faulting and salt tectonics which in many cases appears to have been activated by the faulting. Stratigraphic relations in the sediments indicate that tectonic activity has been episodic in places and separated by reasonably long periods of quiescence. Although tectonic activity in the marginal areas continues to the present, as indicated by several small grabens that offset the latest sediments, overall the deformation decreases from depth toward the seafloor indicating that the marginal areas are becoming less tectonically active.

Sediments in the axial depression exhibit a more intense and closely spaced deformation than in the marginal areas with deformation continuing in many places to offset deeper reflectors and the seafloor by similar amounts. Seismic activity in the northern Red Sea south of the Gulf of Suez area is concentrated in the axial depression, and heat flow profiles completely across the main trough show maximum values that occur consistently over the axial depression, even where it is offset to the west. The small "northern Red Sea type" deeps which appear to be associated with isolated intrusions occur at evenly spaced intervals of between 50 and $60 \mathrm{~km}$ in the axial depression midway between sets of accommodation zones. These observations suggest that extension and the tectonic activity that had previously been distributed across the entire rift is now becoming concentrated in the axial depression and that the

Fig. 16. a. Sea Beam map of escarpment contoured at $20 \mathrm{~m}$ intervals (uncorrected). The escarpment has approximately $100 \mathrm{~m}$ of relief and trends sub-parallel to the Gulf of Aqaba. b. Detail of northwest section of single channel water gun seismic line $2 a$ across escarpment. Ends of the section coincide with labeled arrows shown on Sea Beam map (a). Over 1 s of sediments can be seen dipping in an ESE direction and abruptly terminating against the wall forming the upthrown side of a half-graben. Significance of this feature is discussed in the text. 
extension is beginning to be accompanied by intrusions. The locus of maximum lithospheric thinning as indicated by the heat flow data and the locus of maximum crustal extension as indicated by the observed shallow tectonics are both located in the axial depression. This coincidence is not necessarily predictcd by "simple shear" or "detachment" models (Wernicke and Burchfiel, 1982; Wernecke, 1985; Lister et al., 1986) for extension at continental margins. This question isconsidered in greater detail in Buck et al. (1988).

A well developed axial trough associated with a rough volcanic basement and high amplitude lineated magnetic anomalies exists in the southern Red Sea between $15^{\circ} \mathrm{N}$ and $20^{\circ} \mathrm{N}$. GLORIA sidescan sonar data (Garfunkel et al., 1987) shows that the floor of the axial trough contains many straight, sub-parallel faults that trend in the direction of the axis, a pattern closely resembling that of other slow spreading mid-ocean ridges (Searle and Laughton, 1981). The GLORIA data show that the spreading center is made up of straight segments $30-50 \mathrm{~km}$ long that are offset laterally by 3-10 km across non-transform "relay zones", where the faults locally change strike and the magnetic anomalies are irregular (Garfunkel et al., 1987). Both the magnetic anomalies and the ridge parallel faults extend farther from the axis midway between the relay zones suggesting that spreading initiated in the middle and propagated along strike to eventually coalesce into a single spreading axis (Bonatti, 1985). North of $20^{\circ} \mathrm{N}$ in the Red Sea "transition zone" (see Fig. 1), the continuous spreading axis is replaced by discontinuous cells of seafloor spreading which form the large transition zone deeps which are separated by the shallower, magnetically more quiet "intertrough zones". Seafloor spreading anomaly 2 (1.7 m.y.B.P.) is not present in Atlantis II Deep (the southernmost deep) and it does not appear that the Jaramillo event (0.92 m.y.B.P.) is present over Nereus Deep (the northernmost deep). Thus organized seafloor spreading has developed later in the deeps than in the axial trough, and the initiation of seafloor spreading in the deeps becomes younger to the north.

The development of seafloor spreading in the Red Sea is thus progressing from south to north, but the manner in which the progression takes place is not that of a simple propagating rift tip as suggested by the models of Courtillot (1982) and Courtillot and Vink (1983), nor as observed in oceanic settings (Hey, 1977; Hey and Wilson, 1982). Rather than prolongation of an individual spreading axis, rift propagation is occurring by the establishment of a series of isolated nucleation points which develop as separate seafloor spreading cells that eventually coalesce into a single axis. This observation along with the fairly regular spacing of the nucleation points led Bonatti (1985) to propose a model of "punctiform" initiation of seafloor spreading which he considered to be controlled by a viscosity-density inversion in the underlying asthenosphere resulting in periodically spaced upwellings. This mechanism has also been proposed (Crane, 1985) to explain periodic domal highs that occur in the East Pacific Rise (Macdonald et al., 1984). However, the structural pattern observed in the northern Red Sea suggests that the location of the deeps may be related to and perhaps determined by the pattern of crustal faulting established at the very beginning of rifting. Thus if the nucleation points are due to convective upwellings, the geometry of the convection is being forced by the pre-existing cross features.

Studies of rifts in less advanced stages of development than the northern Red Sea show periodic structures that form early in the development of the rift. Work from the East African rifts indicated that the first stages of extension are characterized by the formation of a main listric normal fault that may curve in plan view (Bosworth et al., 1986). The main normal fault defines an asymmetric half graben geometry within which subsidiary normal faults break up the basement into a series of synthetically faulted blocks. Along strike of the rift another main boundary fault may form which delimits a new set of fault blocks. The main boundary fault and associated fault blocks may have an opposite sense of dip from the previous set and may overlap the adjacent boundary fault to form a complex geometry (Burgess et al., 1987; Rosendahl, 1987). A set of cross-trending normal faults forming an accommodation zone serves to bound the fault block provinces and to take up 
differential motion between the blocks. The East African rift lakes have accommodation zone spacings that are similar to those observed in the northern Red Sea. Typical spacings of $60 \mathrm{~km}$ have been reported for Lake Malawi (Ebinger et al., 1984) and $40 \mathrm{~km}$ for Lake Tanganyika (Burgess et al., in press). The pattern of asymmetric halfgraben fault block provinces separated by accommodation zones observed in East Africa is also well developed in the Gulf of Suez. Three dip provinces have been identified in the Gulf of Suez (Moustafa, 1976) in each of which synthetic normal faults step down across the basin giving it a highly asymmetric cross section (Steckler, 1985). The dip provinces are separated by complexly faulted accommodation zones. These accommodation zones are oriented both oblique to the main boundary fault as is the more frequent case in the East African Rift (Bosworth et al., 1986), and orthogonal to the boundary faults (M. Steckler, pers. commun., 1986).

The Gulf of Suez appears to have developed as part of the early rifting in the northern Red Sea prior to the development of transform motion through the Gulf of Aqaba (Heybroek, 1965; Steckler and Ten Brink, 1986) in the mid-Miocene. Crustal extension in the central Gulf of Suez has been estimated to amount to $25-27 \mathrm{~km}$ (Steckler, 1985), while in the northern Red Sea extension may amount to $135 \mathrm{~km}$ (Cochran, 1983), about a factor of five greater than in the Gulf of Suez. However, at some point between the stage represented by the Gulf of Suez and the late stage rifting of the northern Red Sea, the rift lost the asymmetric half graben nature characteristic of the early stages of rifting and develops a more symmetric profile. This may very well happen through the development of antithetic faults in what has been termed the "rollover" (Gibbs, 1983, 1984) (i.e. the hanging wall).

The spacing of the accommodation zones in the northern Red Sea is similar to that observed in the Gulf of Suez and in the East African rifts. It appears that these features which form early in the rifting history in response to the mechanical and geometric constraints of listric faulting continue to influence the development of the rifting through the development of a mid-ocean ridge.
The gravity, bathymetry and heat flow are consistent with the interpretation that the extension and thinning which had been distributed across the rift becomes increasingly localized near the center of the now symmetric rift resulting in the formation of the axial depression. As the extension and lithospheric thinning increased, the extension which had been accompanied by very small amounts of volcanism in the Gulf of Suez and marginal areas of the northern Red Sea begins to occur through intrusion of large igneous bodies. These intrusions seem to occur in the axial depression halfway hetween accommodation zones. These intrusions result in the formation of the northern Red Sea deeps which with further intrusion appear to serve as nucleation points for the seafloor spreading cells which grow and join to form the mid-ocean ridge. The formation of regularly spaced nucleation points has been suggested to be controlled by periodically spaced gravitational instability behavior of the underlying asthenosphere (Whitehead et al., 1984; Crane, 1985; Bonatti, 1985). Recent studies (Buck, 1986; Steckler, 1985) have shown that small-scale convection can be induced by the geometry of the rift itself. This suggests that the segmentation of the rift by the accommodation zones may serve to control the location of the upwellings and establish the sites of initial emplacement of the large intrusions observed in the axial depression of the northern Red Sea.

\section{Summary and conclusions}

(1) Continental rifting in the northern Red Sea has progressed nearly to the point of initiation of seafloor spreading and has resulted in the formation of two morphologically and geophysically distinct provinces within the main trough which are referred to here as the marginal areas and the axial depression.

(2) The marginal areas form a series of bathymetric terraces that step down from the coastal shelves toward the center of the sea. A pattern of elongate free-air gravity highs and lows trends sub-parallel to the rift and has locally high values that occur consistently over the edges of the bathymetric terraces. Magnetic anomalies are gen- 
erally characterized by low amplitudes and long wavelengths with a few isolated dipolar anomalies. However, lineated seafloor spreading type anomalies are totally absent. The geophysical data imply an underlying basement structure that is composed of tilted basement fault blocks similar to that observed at sediment starved passive margins.

Seismic reflection profiles across the marginal areas show that deformation in the sediments has been dominated by diapirism stemming from a thick evaporite layer that underlies the entire area and by relatively widely spaced faulting. Deformation within these sediments generally decreases upwards indicating an overall lessening of tectonic activity in the marginal areas and in many places discordant packets of sediments suggest episodic activity.

The pattern of gravity highs and bathymetric terraces are offset or terminated along strike across three systematic boundaries that trend perpendicular to the rift and are spaced 50 to $70 \mathrm{~km}$ apart. These boundaries form narrow sinuous clefts in places on the seafloor and can be traced onto shore where they form cross faults that displace basement fault blocks. We interpret these boundaries as accommodation zones which serve to take up differential displacements along strike between sets of basement blocks.

(3) The axial depression forms a narrow (10-25 $\mathrm{km}$ ) continuous region of deeper water that is located near the central part of the Red Sea south of the northern accommodation zone but north of it the axial depression is shifted toward the west in alignment with the Gulf of Suez. Sedimentary sequences including the Miocene evaporites overlay the axial depression and seismic reflection profiles show an intense and more closely spaced deformation which continues in intensity to the present within the sediments in the axial depression. Maximum heat flow values occur in the axial depression and seismicity within the northern Red Sea also appears to be concentrated in the axial depression.

Small deeps associated with large dipolar magnetic anomalies which appear to result from isolated intrusions are found at periodic intervals in the axial depression midway between sets of accommodation zones. These "northern Red Sea" deeps appear to represent an earlier stage of the larger "transition zone" deeps of the central Red Sea which form isolated centers of seafloor spreading.

(4) A model for the development of an "atlantic type" passive margin appears to follow a sequence of well characterized stages exemplified in the Red Sea Rift system (Fig. 17).

The first stage involves the formation of an asymmetric half-graben geometry containing synthetically faulted blocks. Accommodation zones form at this early stage (Ebinger et al., 1984; Bosworth et al., 1986) possibly controlled by various factors including initial curvature of the main boundary fault and mechanical and strength limitations on very long fault blocks. The Gulf of Suez, which developed concurrently with the early rifting in the northern Red Sea, appears to have been arrested at this stage by the development of transform motion through the Gulf of Aqaba.

A second stage develops as the extension progresses and antithetic faults become mechanically favorable in the hanging wall (Gibbs, 1983) resulting in a more symmetric rift profile. Extension is distributed across the entire rift at this stage but motion is probably episodic on individual faults leading to periodic activation of diapirism and the formation of the discordant packets of sediments that are observed associated with the diapirs on the marginal areas of the northern Red Sea

The third stage occurs at even greater extension when the axial depression forms and begins to take up most of the subsequent extension and thinning. Faulting is more closely spaced and heat flow is significantly higher within the axial depression. Intrusions associated with small deeps begin to occur within the axial depression at evenly spaced intervals midway between systematically placed cross-cutting accommodation zones which may be controlling their emplacement.

These small deeps may represent nucleation points which, with continued intrusion and extension, develop into isolated cells of seafloor spreading. Isolated cells of seafloor spreading are present in the central Red Sea transition zone where they form large deeps with similar spacings to that of the northern Red Sea deeps. The continuous seafloor spreading axis of the southern Red Sea 
a) Rift Valley Stage
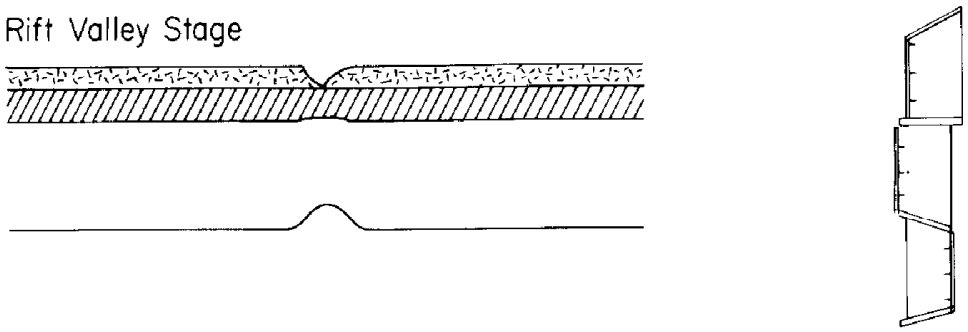

b) Gulf of Suez Stage
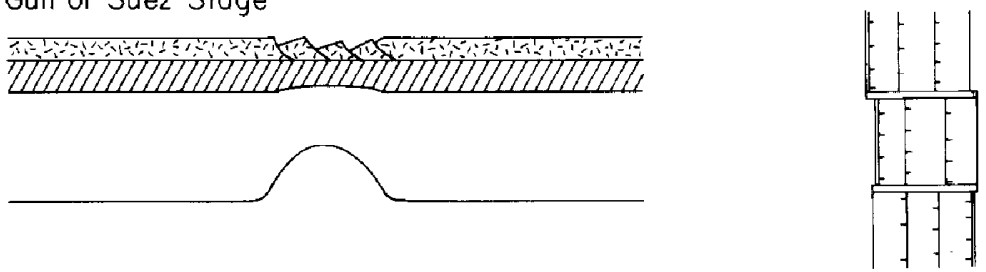

c) Intermediate Stage
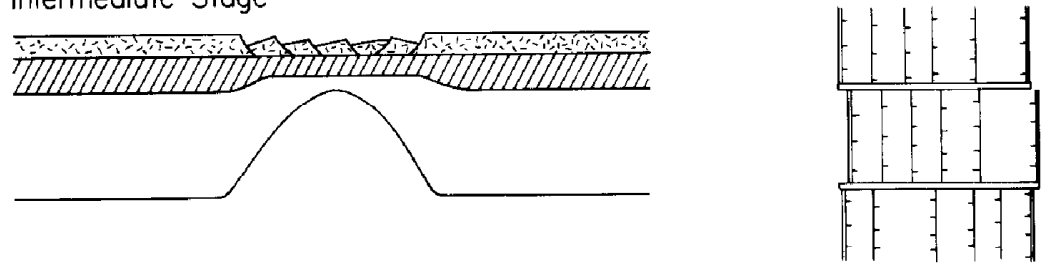

d) Northern Red Sea Stage
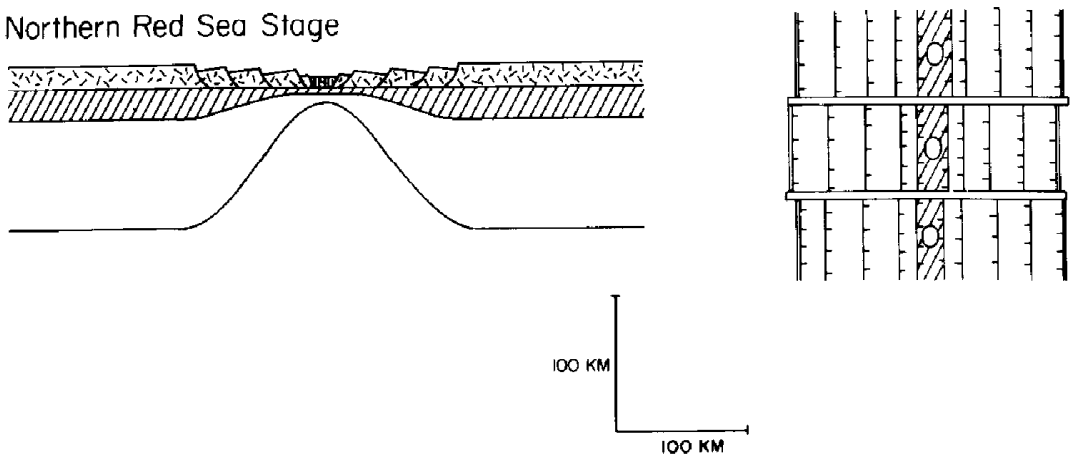

Fig. 17. Sketch showing idealized profiles (on left) and plan views (on right) representing stages in our model for the evolution of a continental rift. (a) Initially a main boundary fault (heavy solid line) forms in the brittle upper crust (stippled) and bottoms over a ductally deforming lower crust (hatched). The thermally defined lithosphere (outline) also ductally thins but experiences a component of thickening due to cooling. The initial fault configuration forms an asymmetric half-graben which in plan view is bounded by accommodation zones (outlined bands) along strike. The accommodation zones take up differential motion between adjacent half-grabens which may reverse dip across them. (b) As extension continues, sets of synthetically faulted blocks develop distributing the extension in the brittle upper crust while the lower crust and lithosphere deform ductally. (c) At greater extension antithetic faults develop and begin to form a more symmetric rift profile. (d) A zone of more pervasive faulting and thinning develops forming the axial depression (vertically ruled in profile, hatched in plan view) where extension and thinning are concentrated. Intrusions (ovals in plan view) begin to accompany the extension and occur between sets of accommodation zones which may control their emplacement. These intrusions represent the initial stages in the formation of isolated cells of seafloor spreading which would then grow and coalesce into a seafloor spreading axis. 
appears to have formed by merging together of individual cells of seafloor spreading.

\section{Acknowledgements}

We would like to express our gratitude to the governments of the Arab Republic of Egypt and of the Kingdom of Saudi Arabia for granting clearance to work in their territorial waters. We would like to thank Captain J. Peterlin, Science Officer J. Smith and all of the officers and crew of $R / V$ "Robert D. Conrad" for their enthusiastic help. We would also like to thank Esso Exploration Co. and in particular P. Miller for encouragement and use of some of their data. The manuscript was reviewed by M. Steckler, E. Bonatti, and Z. Garfunkel. This work was supported by National Science Foundation grant OCE-83-09983. Lamont-Doherty Geological Observatory contribution number 4290 .

\section{References}

Backer, H. and Schoell, M., 1972. New deeps with brines and metalliferous sediments in the Red Sea. Nature (London), Phys. Sci., 240: 153-158.

Barakat, H. and Miller, P., 1984. Geology and petroleum exploration, Safaga Concession, Northern Red Sea, Egypt. 7th Egypt. Gen. Pet. Corp. Explor. Sem., Cairo, 27 pp.

Bell, R.E. and Watts, A.B., 1986. Evaluation of the BGM-3 sea gravity meter system onboard $\mathrm{R} / \mathrm{V}$ Conrad. Geophysics, 51: $1480-1493$.

Ben-Avraham, Z., 1985. Structural framework of the Gulf of Elat (Aqaba), Northern Red Sea. J. Geophys. Res., 90: 703-726.

Bonatti, E., 1985. Punctiform initiation of seafloor spreading in the Red Sea during transition from a continental to an oceanic rift. Nature, 316: 33-37.

Bonatti, E., Colantoni, P., Della Vedova, B. and Taviani, M., 1984. Geology of the Red Sea transitional region $\left(22^{\circ} \mathrm{N}-25^{\circ} \mathrm{N}\right)$. Oceanol. Acta, 7: 385-398.

Bosworth, W., 1985. Geometry of propagating continental rifts. Nature, 316: 625-627.

Bosworth, W., Lambiase, J. and Keisler, R., 1986. A new look at Gregory's rift, the structural style of continental rifting. Eos, Trans. Am. Geophys. Union, 67: 577.

Buck, W.R., 1986. Small-scale convection induced by passive rifting: the cause for uplift of rift shoulders. Earth Planet. Sci. Lett., 77: 362-372.

Buck, W.R., Martinez, F., Steckler, M.S. and Cochran, J.R., 1988. Thermal consequences of lithospheric extension, pure and simple. Tectonics, 7 , in press.
Burgess, C.F., Rosendahl, B.R., Sander, S., Burgess, C.A., Lambiase, J., Derksen, S. and Meader, N., in press. The structural and stratigraphic evolution of Lake Tanganyika: A case study of continental rifting. Am. Assoc. Pet. Geol., Mem.

Cande, S.C. and Mutter, J.C., 1982. A revised identification of the oldest sea-floor spreading anomaly between Australia and Antarctica. Earth Planet. Sci. Lett., 58: 151-161.

Cochran, J.R., 1983. A model for development of Red Sea. Am. Assoc. Pet. Geol. Bull., 67: 41-69.

Cochran, J.R., Martinez, F., Steckler, M.S. and Hobart, M.A., 1986. Conrad Deep: a new northern Red Sea deep. Origin and implications for continental rifting. Earth Planet. Sci. Lett., 78: 18-32.

Coleman, R.G., 1974. Geologic background of the Red Sea, In: R.B. Whitmarsh, O.E. Weser, D.A. Ross, et al., Initial Reports of the Deep Sea Drilling Project, Vol. 23. U.S. Government Printing Office, Washington D.C., pp. 813-819.

Courtillot, V., 1982. Propagating rifts and continental breakup. Tectonics, 1: 239-250.

Courtillot, V. and Vink, G.E., 1983. How continents break up. Sci. Am., 297: 43-49.

Crane, K., 1985. The spacing of rift axis highs: dependence upon diapiric processes in the underlying asthenosphere? Earth Planet. Sci. Lett., 72: 405-414.

Daggett, P.H., Morgan, P., Boulos, F.K., Hennin, S.F., ElSherif, A.A., El-Sayed, A.A., Basta, N.Z. and Melek, Y.S., 1986. Seismicity and active tectonics of the Egyptian Red Sea margin and the Northern Red Sea. Tectonophysics, 125: $313-324$

Degens, E.T. and Ross, D.A. (Editors), 1969. Hot brines and recent heavy metal deposits in the Red Sea. Springer, New York, N.Y., 600 pp.

Drake, C.L. and Girdler, R.W., 1964. A geophysical study of the Red Sea. Geophys. J.R. Astron. Soc., 8: 473-495

Ebinger, C.J., Crow, M.J., Rosendahl, B.R., Livingstone, D.A. and LeFournier, J., 1984. Structural evolution of Lake Malawi, Africa. Nature, 308: 627-629.

Garfunkel, Z., Ginzburg, A. and Searle, R.C., 1987. Fault pattern and mechanism of crustal spreading along the axis of the Red Sea from side scan sonar (GLORIA) data. Ann. Geophys., 5B (2); 187-200.

Garson, M.S. and Krs, M., 1976. Geophysical and geological evidence of the relationship of Red Sea transverse tectonics to ancient fractures. Geol. Soc. Am. Bull., 87: 169-181.

Gibbs, A.D., 1983. Balanced cross-section construction from seismic sections in areas of extensional tectonics. J. Struct. Geol., 5: 153-160.

Gibbs, A.D., 1984. Structural evolution of extensional basin margins. J. Geol. Soc. London, 141: 609-620.

Greene, D.C., 1984. Structural geology of the Quseir area, Red Sea Coast, Egypt, Report No. 57. Department of Geology and Geography, Univ. of Massachusetts, Amherst, Mass. $159 \mathrm{pp}$.

Hey, R.N., 1977. A new class of "pseudofaults" and their 
bearing on plate tectonics: a propagating rift model. Earth Planet. Sci. Lett., 37: 321-325.

Iley, R.N. and Wilson, D.S., 1982. Propagating rift explanation for the tectonic evolution of the northeast Pacific-the pseudomovie. Earth Planet. Sci. Lett., 58: 167-188.

Heybroek, F., 1965. The Red Sea Miocene evaporite basin. In: Salt Basins Around Africa. The Institute of Petroleum, London, pp. 17-40.

Hobart, M.A., Cochran, J.R., Martinez, F. and Steckler, M.S., 1985. The northern Red Sea III: heat flow and thermal state of the lithosphere (abstr.). Eos, Trans. Am. Geophys. Union, 66 (18).

Jackson, M.P.A. and Talbot, C.J., 1986. External shapes, strain rates and dynamics of salt structures. Geol. Soc. Am. Bull., 97: 305-323.

Jansa, L.F., Bujak, J.P. and Williams, G.L., 1980. Upper Triassic salt deposits of the western North Atlantic. Can. J. Earth Sci., 17: 547-559.

Knott, S.T., Bunce, E.T. and Chase, R.L., 1966. Red Sea seismic reflection studies. In: International Upper Mantle Project, the World Rift System. Geol. Surv. Can., Pap., 66-14: 33-61.

Lemon, N.M., 1985. Physical modeling of sedimentation adjacent to diapirs and comparison with Late Precambrian Oratunga breccia body in central Flinders Ranges, South Australia. Am. Assoc. Pet. Geol. Bull., 69: 1327-1338.

Lister, G.S., Etheridge, M.A. and Symonds, P.A., 1986. Detachment faulting and the evolution of passive continental margins. Geology, 14: 246-250.

Macdonald, K., Sempere, J.C. and Fox, P.J., 1984. East Pacific Rise from Siqueiros to Orozco Fracture Zones: along-strike continuity of axial neovolcanic zone and structure and evolution of overlapping spreading centers. J. Geophys. Res., 89: 6049-6069.

Mart, Y. and Hall, J.K., 1984. Structural trends in the northern Red Sea. J. Geophys. Res., 89: 11352-11364.

Mart, Y. and Rabinowitz, P.D., 1986. The Northern Red Sea and the Dead Sea rift. Tectonophysics, 124: 85-113.

Montadert, L., De Charpal, O., Roberts, D., Guennoc, P. and Sibuet, J., 1979. Northeast Atlantic passive continental margins: rifting and subsidence processes. In: M. Talwani, W. Hay, and W.B.F. Ryan (Editors), Deep Drilling Results in the Atlantic Ocean; Continental Margins and Paleoenvironments, Maurice Ewing Symp., Proc. Ser., 3: 154-186.

Moustafa, A.M., 1976. Block faulting in the Gulf of Suez. 5th Egypt. Gen. Pet. Corp., Explor. Sem. (Cairo), 10 pp.

Pautot, G., 1983. Les fosses de la Mer Rouge: approche géomorphologique d'un stade initial d'ouverture océanique réalisée à l'aide du Seabeam. Oceanol. Acta., 6: 235-244.

Pautot, G., Guennoc, P., Coutelle, A. and Lyberis N., 1984. Discovery of a large brine deep in the northern Red Sea. Nature, 310: 133-136.

Pautot, G., Guennoc, P., Coutelle, A. and Lyberis, N., 1986. La Dépression axiale du segment nord Mer Rouge (de $25^{\circ}$ à $28^{\circ} \mathrm{N}$ ): nouvelles données géologiques et géophysiques obtenues du cours de la campagne Transmerou 83. Bull. Soc. Géol. Fr., 8: 381-399.

Phillips, J.D. and Ross, D.A., 1970. Continuous seismic reflec- tion profiles in the Red Sea. Philos. Trans. R. Soc. London, Ser. A, 267:143-152.

Richardson, M., 1982. A depositional model for the Cretaceous Duwi (phosphate) formation of Quseir, Red Sea Coast of Egypt. M.S. Thesis, Univ. of South Carolina, Columbia, S.C., 395 pp.

Roeser, H.A., 1975. A detailed magnetic survey of the southern Red Sca. Gcol. Jahrb., 13: 131-153.

Rosendahl, B.R., 1987. Architecture of continental rifts with special reference to East Africa. Ann. Rev. Earth Planet. Sci., 15:445-503.

Rosendahl, B.R. and Livingstone, D.A., 1983. Rift lakes of East Africa: new seismic data and implications for future research. Episodes, 1: 14-19.

Searle, R.C. and Laughton, A.S., 1981. Fine-scale sonar study of tectonics and volcanism on the Reykjanes Ridge. Proc. Int. Geol. Congr., 26th, Paris, Geology of the Oceans Symp. Oceanol. Acta, supplement to Vol. 4, 5-13.

Searle, R.C. and Ross, D.A., 1975. A geophysical study of the Red Sea axial trough between $20.5^{\circ}$ and $22^{\circ} \mathrm{N}$. Geophys. J.R. Astron. Soc., 43: 555-572.

Seni, S.J. and Jackson, M.P.A., 1983. Evolution of salt structures, East Texas Diapir Province. Part 2: Sedimentary record of halokinesis. Am. Assoc. Pet. Geol. Bull., 67: 1219-1244.

Schurmann, H.M.E., 1966. The Precambrian along the Gulf of Suez and the Northern Part of the Red Sea. Brill, Leiden, 404 pp.

Steckler, M.S., 1985. Uplift and extension at the Gulf of Suez, indications of induced mantle convection. Nature, 317: 135-139.

Steckler, M.S. and Ten Brink, U.S., 1986. Lithospheric strength variations as a control on new plate boundaries: examples from the northern Red Sea region. Earth Planet. Sci. Lett., 79: $120-132$.

Stern, R.J., Gottfried, D. and Hedge, C.E., 1984. Late Precambrian rifting and crustal evolution in the north eastern desert of Egypt. Geology, 12: 168-172.

Stoeser, D.B. and Camp, V.E., 1985. Pan-African microplate accretion of the Arabian Shield. Geol. Soc. Am. Bull., 96: 817-826.

Talwani, M., 1970. Developments in navigation and measurement of gravity at sea. Geoexploration, 8: 151-183.

Talwani, M., Worzel, L.J. and Landisman, M., 1959. Rapid gravity computations for two-dimensional bodies with application to the Mendocino submarine fracture zone. J. Geophys. Res., 64: 49-59.

Uchupi, E. and Ross, D., 1986. The tectonic style of the northern Red Sea. Geo-Mar. Lett., 5: 203-209.

Wernicke, B., 1985. Uniform sense normal simple shear of the continental lithosphere. Can. J. Earth Sci., 22:108-125.

Wernicke, B. and Burchfiel, B.C., 1982. Modes of extensional tectonics. J. Struct. Geol., 1:105-115.

Whitehead, S.A., Dick, H.B. and Shouten, H., 1984. A mechanism for magmatic accretion under spreading centers. Nature, 312: 146-148.

Whitmarsh, R.B., Weser, O.E., Ross, D.A., et al., 1974. Initial Reports of the Deep Sea Drilling Project, 23 B. U.S. Government Printing Office, Washington D.C., 1180 pp. 